\title{
Nonclinical Cardiovascular Studies of Prucalopride, a Highly Selective 5-Hydroxytryptamine 4 Receptor Agonist ${ }^{[}$
}

\author{
Kelly Conlon, Joris H. De Maeyer, Chris Bruce, Jan A. J. Schuurkes, Lee Christie, \\ James McRedmond, Katayoun Derakhchan, and Paul R. Wade \\ Nonclinical Development, Shire, Basingstoke, United Kingdom (K.C., C.B.); Shire-Movetis, Turnhout, Belgium (J.H.D.M., \\ J.A.J.S.); Biopta Ltd, Glasgow, United Kingdom (L.C.); Java Clinical Research, Dublin, Ireland (J.M.); and Nonclinical \\ Development, Shire, Lexington, Massachusetts (K.D., P.R.W.)
}

Received July 18, 2017; accepted October 31, 2017

\begin{abstract}
Patients with chronic constipation benefit from treatment with 5-hydroxytryptamine $4\left(5-\mathrm{HT}_{4}\right)$ receptor agonists. However, the first-generation $5-\mathrm{HT}_{4}$ receptor agonists cisapride and tegaserod were withdrawn from the market owing to rare cardiovascular adverse events that were not $5-\mathrm{HT}_{4}$-receptor-related but due to the lack of selectivity of these drugs. Here we report the nonclinical cardiovascular profile of the selective $5-\mathrm{HT}_{4}$ receptor agonist prucalopride. To assess its non- $5-\mathrm{HT}_{4}$ receptor-mediated effects on cardiovascular electrophysiological parameters, in vitro studies were performed in human ether-à-go-go-related genetransfected cells, guinea pig ventricular myocytes and papillary muscle preparations, rabbit and dog Purkinje fibers, and the Langendorff rabbit heart. In vivo experiments were performed in a rabbit model for drug-induced proarrhythmogenesis, in anesthetized guinea pigs, and anesthetized and conscious dogs. In
\end{abstract}

addition, human platelet aggregation and coronary artery contraction were studied to exclude interactions that have been suggested to mediate the cardiovascular effects of tegaserod. Effects at $5-\mathrm{HT}_{4}$ receptors were evaluated in piglet and human atrial myocardium, and in anesthetized pigs. Finally, cardiovascular endpoints were investigated in chronic, repeated-dose toxicology studies at very high prucalopride doses in rats and dogs. No relevant effects were observed in any of the cardiovascular studies at concentrations at least 50 times the therapeutic plasma level. Only in pigs were minor and transient increases in heart rate and blood pressure noted upon first exposure to prucalopride, at plasma levels at least 10 times higher than human therapeutic plasma levels. Prucalopride may thus provide therapeutic benefit without the cardiovascular risks reported for other $5-\mathrm{HT}_{4}$ receptor agonists.

\section{Introduction}

Chronic constipation is a common and often debilitating problem that impacts health-related quality of life and imposes a substantial economic burden (Bosshard et al., 2004; Dennison et al., 2005; Wald et al., 2007). It can be particularly debilitating in elderly patients (Bosshard et al., 2004; Dennison et al., 2005). Prevalence estimates of constipation range from 12 to $19 \%$; however, the true prevalence may be underestimated because not all patients seek medical advice (Higgins and Johanson, 2004). Many

This study was funded by Shire-Movetis NV, Turnhout, Belgium. Studies conducted at Biopta and Java Clinical Research were funded by Shire. Funding for medical writing support was provided by Shire. Conflicts of interest: K.C., C.B., and P.R.W., are previous employees of Shire. K.D. is an employee of Shire. J.H.D.M. and J.A.J.S. are previous employees of ShireMovetis. L.C. is an employee of Biopta Ltd and J.M. is an employee of Java Clinical Research, both of which received funding from Shire to conduct the presented studies.

https://doi.org/10.1124/jpet.117.244079.

S This article has supplemental material available at jpet.aspetjournals.org. patients benefit from treatments that increase gastrointestinal motility, such as 5 -hydroxytryptamine $4\left(5-\mathrm{HT}_{4}\right)$ receptor agonists (Gershon and Tack, 2007). However, adverse cardiovascular events have led to the withdrawal of the first-generation $5-\mathrm{HT}_{4}$ receptor agonists cisapride (Propulsid; Janssen Pharmaceutica, Beerse, Belgium) and tegaserod (Zelnorm; Novartis, East Hanover, NJ). Adverse cardiovascular events that were not $5-\mathrm{HT}_{4}$ receptor-related have been observed with these compounds (http:// www.fda.gov/downloads/AdvisoryCommittees/CommitteesMeetingMaterials/Drugs/GastrointestinalDrugsAdvisoryCommittee/ UCM279736.pdf).

Cisapride has been associated with QT prolongation, torsade de pointes and other ventricular arrhythmias, and more rarely with sudden death, (notably in patients with predisposing conditions such as a history of cardiac disease, or when coadministered with other medications that inhibit the metabolism of cisapride) (Mohammad et al., 1997; Rampe et al., 1997). It has been demonstrated that cisapride has less than 10 -fold selectivity for the $5-\mathrm{HT}_{4}$ receptor over the human ether-à-go-go-related gene $(h E R G)$ channel

ABBREVIATIONS: AAP, amplitude of resting action potential; APD, action potential duration; $A P D_{x}$, action potential duration at $x \%$ repolarization; $A U C$, area under the curve; $A V$, atrioventricular; $C_{\max }$, maximum plasma concentration; $C R C$, concentration-response curve; ERP, effective refractory period; GR113808, 1-(2-methylsulfonylaminoethyl-4-piperidinyl)methyl-1-methyl-1H-indole-3-carboxylate; $h E R G$, human ether-à-go-gorelated gene; 5-HT, 5-hydroxytryptamine; 5- $\mathrm{HT}_{x}$, 5-hydroxytryptamine receptor $\mathrm{x}$; JT, duration of ventricular repolarization interval; JTc, corrected $\mathrm{JT} ; \mathrm{LVdP} / \mathrm{dt}_{\max }$, maximum rate of change in isovolumic left ventricular pressure; LVdP/dt $\mathrm{din}_{\text {, }}$, cardiac relaxation; LVEDP, left ventricular end-diastolic pressure; QTc, corrected QT interval; $V_{\max }$, maximum rate of depolarization during the upstroke. 
(De Maeyer et al., 2008), and that hERG inhibition occurs within the therapeutic plasma concentration range of cisapride (Mohammad et al., 1997; Rampe et al., 1997; Potet et al., 2001; Redfern et al., 2003).

Tegaserod may be associated with rare occurrences of serious cardiovascular ischemic events such as unstable angina, heart attack, or stroke (http://www.fda.gov/Drugs/ DrugSafety/PostmarketDrugSafetyInformationforPatientsandProviders/ucm051284.htm). Possible explanations for this include the effect of tegaserod on $5-\mathrm{HT}_{1}$ or $5-\mathrm{HT}_{2}$ receptor activity, which may lead to coronary artery constriction or platelet aggregation (De Maeyer et al., 2008). Tegaserod was withdrawn from the US market in 2007 but was subsequently made available under a restricted use regulation. In 2008, this license was withdrawn, and tegaserod is currently an emergency investigational new drug only. However, both an observational cohort study and a matched case-control study have demonstrated that the incidence of cardiovascular ischemic events was similar in tegaserod users and controls (Anderson et al., 2009; Loughlin et al., 2010).

The selective $5-\mathrm{HT}_{4}$ receptor agonists velusetrag and naronapride are in development for gastrointestinal indications. Although published data are limited, neither agent has yet demonstrated significant cardiovascular safety concerns (Smith et al., 2008; http://www.fda.gov/downloads/AdvisoryCommittees/CommitteesMeetingMaterials/Drugs/GastrointestinalDrugsAdvisoryCommittee/UCM279736.pdf; Tack et al., 2012).

Prucalopride (Resolor; Shire Pharmaceuticals, Dublin, Ireland) is approved in Europe, Canada, Asia, and Australia for the treatment of chronic idiopathic constipation in adults for whom laxatives have failed to provide adequate relief (http://www.ema.europa.eu/docs/en_GB/document_library/ EPAR_-_Product_Information/human/001012/WC500053998.pdf). The efficacy of prucalopride in increasing the frequency of bowel movements and improving patient-reported symptoms and quality of life has been demonstrated in a series of phase III trials (Camilleri et al., 2008; Quigley et al., 2009; Tack et al., 2009; Yiannakou et al., 2015). The recommended clinical dose of prucalopride is $2 \mathrm{mg}$ once daily in adults, which corresponds to a maximum plasma concentration $\left(\mathrm{C}_{\max }\right)$ of approximately $7.5 \mathrm{ng} / \mathrm{ml}$ or $20 \mathrm{nM}$ (Tack and Corsetti, 2012), and an area under the plasma concentration-time curve of $109 \mathrm{ng} / \mathrm{h}$ per milliliter as measured at steady state in a 7-day repeated-dosing study.

Prucalopride is a highly selective $5-\mathrm{HT}_{4}$ receptor agonist [affinity (pKi) = 8.7 nM; Fig. 1] (De Maeyer et al., 2008). In vitro, its affinity for the $5-\mathrm{HT}_{4}$ receptor is at least 200 -fold greater than its affinity for other receptors and ion channels (Briejer et al., 2001), and it demonstrates none of the offtarget interactions of cisapride or tegaserod (De Maeyer et al., 2008; Mendzelevski et al., 2012). As part of safety pharmacology and toxicology programs, an extensive set of nonclinical cardiovascular studies was undertaken with prucalopride in a variety of in vitro and in vivo models, at concentrations covering and exceeding therapeutic doses in man. Throughout this article, safety margins for prucalopride are estimated on the basis of comparisons of doses and plasma levels in various animal species with the therapeutic dose and plasma level in humans.

\section{Materials and Methods}

\section{Study Design}

Ethical approval for the platelet aggregation study was obtained from the Research Ethics Committee of St. Vincent's University Hospital, Dublin, Ireland. Written informed consent was obtained from all subjects prior to initiation of the study. In vivo animal studies were approved by the relevant authorities. Studies were conducted according to standard operating procedures [Janssen Research Foundation (Beerse, Belgium), Java Clinical Research (Dublin, Ireland), Biopta Ltd (Glasgow, UK)]. The study locations are listed in Supplemental Information 1.

\section{Non-5-HT 4 Receptor-Mediated Cardiovascular Pharmacology}

A range of in vitro and in vivo studies were conducted to evaluate the safety pharmacology of prucalopride. A broad set of studies was implemented to fully exclude all potential non-5-HT 4 receptormediated cardiovascular interactions that have been observed with cisapride and tegaserod.

\section{In Vitro Studies}

Electrophysiological Effects on the hERG Channel in Cultured Human Cells. The inhibition of the delayed rectifier potassium current by prucalopride $0.01-100 \mu \mathrm{M}$ was assessed in $h E R G$-transfected human embryonic kidney cells (HEK293; purchased from the University of Wisconsin, Madison, WI) using a whole-cell voltage clamp technique (Zhou et al., 1998). As a reference, the effects of ketoconazole $0.3-30 \mu \mathrm{M}$, terfenadine $0.01-0.1 \mu \mathrm{M}$, and erythromycin 3-100 $\mu \mathrm{M}$ were evaluated and compared with those of prucalopride. In addition, to study potential drug interactions, prucalopride $0.01-30 \mu \mathrm{M}$ was evaluated in combination with ketoconazole $3 \mu \mathrm{M}$, terfenadine $0.03 \mu \mathrm{M}$, or erythromycin $10 \mu \mathrm{M}$ (concentrations that resulted in 62,60, and 9\% inhibition of the hERG current, respectively). Changes in the hERG current were quantified as the percentage inhibition compared with control ( $0.3 \%$ dimethyl sulfoxide). Data were evaluated using a two-tailed Student $t$ test for independent samples. Methodological details are described in Supplemental Information 2 .

Electrophysiological Effects in Guinea Pig Ventricular Myocytes. Standard patch clamp techniques were used to investigate the effect of prucalopride $10 \mathrm{nM}-10 \mu \mathrm{M}$ on the rapid $\left(\mathrm{I}_{\mathrm{Kr}}\right)$ and slow $\left(\mathrm{I}_{\mathrm{Ks}}\right)$ components of the delayed rectifier and inward rectifier $\left(\mathrm{I}_{\mathrm{K} 1}\right)$ potassium currents, the fast sodium current $\left(\mathrm{I}_{\mathrm{Na}}\right)$ and the L-type calcium current $\left(\mathrm{I}_{\mathrm{Ca}(\mathrm{L})}\right)$. A broad concentration range of prucalopride was chosen to cover and exceed human plasma levels. Data were analyzed using Student's $t$ tests as appropriate. Methodological details are described in Supplemental Information 3.

Electrophysiological Effects in Isolated Rabbit and Dog Purkinje Fibers. The effects of prucalopride up to $10 \mu \mathrm{M}$ on the following electrophysiological parameters were investigated in isolated Purkinje fibers (rabbits $n=8$; $\operatorname{dogs} n=7$ ) and compared with control (water): amplitude of resting action potential (AAP), action potential duration at $90 \%$ repolarization $\left(\mathrm{APD}_{90}\right)$, effective refractory period (ERP), resting membrane potential (RMP), recovery time of the action potential (RT) and the maximum rate of depolarization during the upstroke $\left(\mathrm{V}_{\max }\right)$. Supratherapeutic concentrations of prucalopride were selected for these studies to enable the detection of any effects. Measurements were performed using microelectrode techniques similar to those previously described (Carmeliet et al., 1976; Carlsson et al., 1997; Adamantidis et al., 1998). Experiments were performed during normal rhythm (1 Hz; rabbit, dog) and during bradycardia $(0.2 \mathrm{~Hz}$; rabbit). All experiments were performed under normokalemia ( $\mathrm{KCl} 4 \mathrm{mM})$. Data were analyzed using the Mann-Whitney $U$ test or Fisher's exact test as appropriate. Methodological details are described in Supplemental Information 4. 

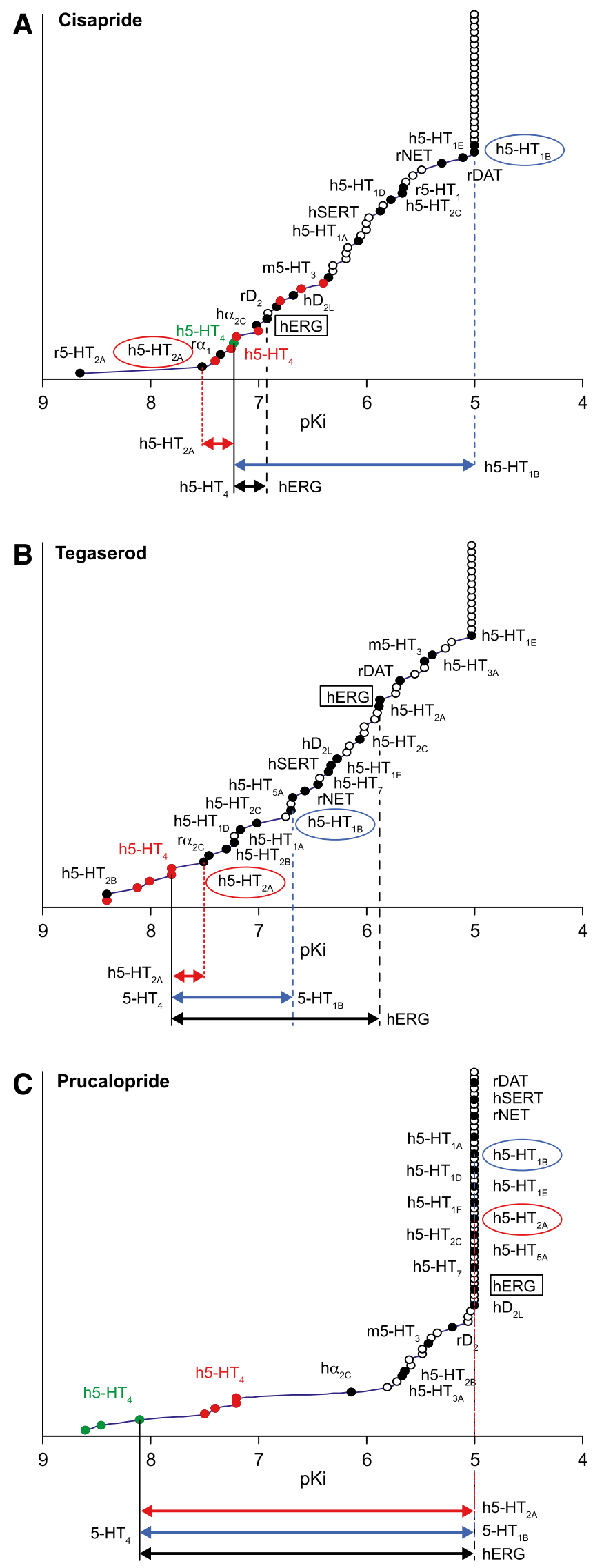

Fig. 1. Binding selectivity of the $5-\mathrm{HT}_{4}$ receptor agonists cisapride (A), tegaserod (B), and prucalopride (C). Plots show the results of competitive
Electrophysiological Effects in Isolated Guinea Pig Papillary Muscle. Microelectrode techniques were used to investigate the effects of prucalopride on the following electrophysiological parameters in isolated guinea pig papillary muscle $(n=7)$ : action potential duration at $50 \%$ repolarization $\left(\mathrm{APD}_{50}\right), \mathrm{APD}_{90}, \mathrm{AAP}, \mathrm{RMP}, \mathrm{V}_{\max }$ and contractile force. A broad range of concentrations (0.01-10 $\mu \mathrm{M})$ was tested to cover therapeutic and supratherapeutic concentrations. To compare the potential effects of prucalopride under different conditions, experiments were performed during normal rhythm $(1 \mathrm{~Hz})$ bradycardia $(0.25 \mathrm{~Hz})$, normokalemia $(\mathrm{KCl} 4 \mathrm{mM})$, and hypokalemia $(\mathrm{KCl} 2.7 \mathrm{mM})$. Data were analyzed using the Mann-Whitney $U$ test or the Student's $t$ test, as appropriate. Methodological details are described in Supplemental Information 5.

Electrophysiological Effects in the Isolated Langendorff Rabbit Heart [Hondeghem Model (Hondeghem et al., 2001)]. The potential of prucalopride to exert proarrhythmogenic effects at concentrations up to $10 \mu \mathrm{M}$ was investigated in hearts obtained from albino rabbits of either sex $(n=16$; weight approximately $2.5 \mathrm{~kg})$. The hearts were paced at different cycle lengths (250-2000 milliseconds) and the following parameters were assessed: coronary perfusion, APD, triangulation, instability, proarrhythmia, slowing of conduction, automaticity and escape cycle lengths, and threshold of stimulation current. In a subsequent study in female rabbits $(n=10$; weight $2.5 \mathrm{~kg}$ ), the electrophysiological effects of prucalopride were studied in the presence and absence of erythromycin $100 \mu \mathrm{M}$ or ketoconazole $10 \mu \mathrm{M}$. Observed effects were compared with those of vehicle; data were analyzed for significance using analysis of variance and a Scheffé test for $95 \%$ confidence, or Friedman test followed by Wilcoxon signed-rank test, as appropriate. Methodological details for both studies are provided in Supplemental Information 6.

Platelet Aggregation in Human Blood Samples. The purpose of these studies was to investigate the effect of prucalopride 20,60 , and $200 \mathrm{nM}$ (approximately 1, 3, and 10 times the $\mathrm{C}_{\max }$ in clinical studies, respectively) (Tack and Corsetti, 2012) on human platelet function. For comparison, tegaserod $100 \mathrm{nM}$ and 5-HT $50 \mathrm{nM}$ were also included. Blood samples were obtained from 20 healthy volunteers ( 7 men, 13 women; mean age $35 \pm 12$ years) who were free from drugs likely to affect the platelet response, 5-HT levels, or 5-HT receptors. Light-transmission aggregometry analysis was conducted within 3 hours of blood draw using a PAP-8E aggregometer (Bio/Data Corp., Horsham, PA). Effects of $5-\mathrm{HT}_{4}$ receptor agonists were evaluated in platelet-rich plasma (PRP) samples $(n=17)$ that were challenged with one of three platelet activators: $\mathrm{ADP} 1.5 \mu \mathrm{M}$; thrombin receptoractivating peptide (TRAP) $1 \mu \mathrm{M}$; or epinephrine $2.5 \mu \mathrm{M}$ plus 5 -HT $0.5 \mu \mathrm{M}$. 5-HT alone does not induce platelet aggregation but can enhance the response to epinephrine (Jin and Kunapuli, 1998). To evaluate the contribution of $5-\mathrm{HT}_{4}$ and $5-\mathrm{HT}_{2 \mathrm{~A}}$ receptors to platelet responses to 5 -HT, PRP $(n=14)$ was incubated for 45 minutes with the $5-\mathrm{HT}_{3} / 5-\mathrm{HT}_{4}$ receptor antagonist SDZ 205-557 $400 \mathrm{nM}$, the $5-\mathrm{HT}_{2 \mathrm{~A}}$ receptor antagonist ketanserin $100 \mathrm{nM}$, and two controls (water and $0.0002 \%$ ethanol in physiologic buffer) before challenge with

receptor-ligand binding studies using agonist (green or black circles) and antagonist radioligands (red or white circles). The $x$-axis shows the binding affinity ( $\mathrm{pKi}$ ) of the compound at various receptors and ion channels. Labels indicate the different receptors and ion channels for which the affinities of each compound were tested. The arrows below each graph show the difference in affinity of each compound for the $5-\mathrm{HT}_{4}$ receptor compared with the $5-\mathrm{HT}_{2 \mathrm{~A}}$ receptor (red ellipsis), the $5-\mathrm{HT}_{1 \mathrm{~B}}$ receptor (blue ellipsis), or the $h E R G$-encoded potassium channel (black rectangle). Prefixes indicate human- $(\mathrm{h})$, rat- $(\mathrm{r})$, or mouse- $(\mathrm{m})$ derived receptors. $\alpha_{1}$, alpha- 1 adrenergic receptor; $\alpha_{2} \mathrm{C}$, alpha-2C adrenergic receptor; $\mathrm{D}_{2}$, dopamine receptor 2; DAT, dopamine transporter; $\mathrm{D}_{2} \mathrm{~L}$, dopamine receptor 2L; 5-HT, 5-hydroxytryptamine; NET, norepinephrine transporter; SERT, serotonin transporter. Figure adapted from De Maeyer et al. (2008) Neurogastroenterol Motil 20: 99-112 with the permission of Blackwell Publishing. 
epinephrine plus 5-HT. The maximum aggregation percentage was calculated for each test condition, and data were analyzed using Friedman's test and Dunn's post-test as appropriate. Additional methodological details are described in Supplemental Information 7.

Contractility Assessment in Dog, Pig, and Human Isolated Coronary Arteries. The effect of increasing concentrations of prucalopride on the contractility of isolated dog, pig, and human coronary arteries was investigated and compared with that of tegaserod and 5-HT. Dog hearts ( $n=5$; one male, four female; $13-29$ months old; weight 9.1-13.6 kg) were obtained from Harlan Laboratories UK Ltd (Loughborough, UK). Pig hearts $(n=5)$ were obtained from a local (UK) abattoir; all animals were drug naïve. Healthy human hearts (free of stents, pacemakers, hypertension, ventricular hypertrophy, heart disease, or history of myocardial infarction) were obtained from five deceased donors [three men, two women; mean age 48 years (range 19-66 years)]. Four of the five donors were free of medications that were likely to affect 5-HT levels or 5-HT receptors (e.g., serotonin-norepinephrine reuptake inhibitors, selective serotonin reuptake inhibitors, or statins). One donor had been taking venlafaxine (a serotonin-norepinephrine reuptake inhibitor) on a long-term basis.

Tissues were primed with 5-HT $(3 \mu \mathrm{M})$ and, after a washout, cumulative concentration-response data were collected for each artery preparation with the following: 1) prucalopride $1 \mathrm{nM}-10 \mu \mathrm{M}$, 2) tegaserod $1 \mathrm{nM}-10 \mu \mathrm{M}$, or 3) 5 -HT $1 \mathrm{nM}-10 \mu \mathrm{M}$, and compared with solvent-treated tissues. Concentration-response curves (CRCs) were constructed as a percentage of the initial 5-HT priming response, and two-way analysis of variance was applied to identify statistically significant differences between treatments. Additional methodological details are described in Supplemental Information 8.

\section{In Vivo Studies}

Cardiovascular Parameters in Anesthetized Rabbits and Guinea Pigs. The potential proarrhythmogenic effects of prucalopride were investigated in a methoxamine-infused anesthetized rabbit model sensitized to drug-induced polymorphic ventricular tachycardia and torsade de pointes. Prucalopride was intravenously administered to male New Zealand White rabbits $(n=7$ per dose; weight $2.5-3.5 \mathrm{~kg}$ ) at doses of $0.04,0.08,0.16$ and $0.31 \mathrm{mg} / \mathrm{kg}$ per minute for 60 minutes (corresponding to total doses of 2.4, 4.8, 9.6, and $18.6 \mathrm{mg} / \mathrm{kg}$, respectively).

The potential cardio-hemodynamic and electrophysiological effects of prucalopride were assessed in two studies in anesthetized guinea pigs. In these studies, mean arterial blood pressure, heart rate, all time intervals of the ECG [QRS, RR, PR, QT, JT (duration of ventricular repolarization), QTc (corrected QT interval), JTc (corrected JT interval)], the amplitude of the $P$ and $R$ waves, the incidences of conduction disturbance, ventricular premature beats, polymorphic ventricular tachycardia, ventricular fibrillation, and sudden death were recorded. The first study was performed in male Dunkin Hartley guinea pigs ( $n=9$; weight $560-760 \mathrm{~g}$ ). Prucalopride $1.25 \mathrm{mg} / \mathrm{kg}$ was administered intravenously over a period of 5 minutes; an additional comparator group ( $n=9$ ) was intravenously administered solvent. In the second study, male Dunkin Hartley guinea pigs ( $n=13$ per dose; weight 505-760 g) were intravenously administered prucalopride at supratherapeutic concentrations of $1.25,2.5,5$, or $10 \mathrm{mg} / \mathrm{kg}$ over a period of 5 minutes. The effects of prucalopride were compared with those of equal volumes of solvent $(n=18)$. Data were analyzed using the Mann-Whitney $U$ test or Fisher's exact test, as appropriate. Additional methodological details are provided in Supplemental Information 9.

Cardiovascular Parameters in Anesthetized Dogs. Anesthetized dogs (adult male Beagle dogs; $n=7$ per dose group; weight 10.4-16.3 kg; varying ages) were intravenously administered increasing doses of prucalopride $0.02,0.04,0.08,0.16,0.63$, and $1.25 \mathrm{mg} / \mathrm{kg}$ (total cumulative dose $2.5 \mathrm{mg} / \mathrm{kg}$ ) or control at 30 -minute intervals. In a second study, anesthetized dogs (adult male Beagle dogs; $n=7$ per dose group; weight 9.7-15.1 kg; less than 3-years-old) were intravenously administered increasing high doses of prucalopride $(0.63-5 \mathrm{mg} / \mathrm{kg}$; total dose $9.38 \mathrm{mg} / \mathrm{kg})$. The following parameters were measured: heart rate, systolic and diastolic aortic blood pressure, left ventricular end-diastolic pressure (LVEDP), the maximum rate of change in isovolumic left ventricular pressure $\left(\mathrm{LVdP} / \mathrm{dt}_{\max }\right)$, cardiac relaxation $\left(\mathrm{LVdP} / \mathrm{dt}_{\min }\right)$, the time constant of relaxation, contractility index (defined as the maximum first derivative divided by the actual pressure in the left ventricle), pressure rate product, cardiac output, stroke volume, coronary blood flow, systemic vascular resistance, $\mathrm{PQ}$ interval, QRS duration, and QT and QTc intervals. Differences between control-treated groups and prucalopride-treated groups of less than $10 \%$ of the median peak values were considered to be of no physiological relevance, even if they were statistically significant. Data were analyzed using the Mann-Whitney $U$ test. Methodological details are provided in Supplemental Information 10.

\section{Cardiovascular and Behavioral Parameters in Conscious Adult Dogs}

Cardiovascular and behavioral parameters in response to prucalopride were evaluated in three separate conscious dog studies, with different routes of administration. In the first study, a low, single dose of $0.31 \mathrm{mg} / \mathrm{kg}$ was administered orally to awake, chronically instrumented dogs ( $n=7$; weight $11.0-13.0 \mathrm{~kg}$; varying ages). An additional group $(n=7)$ received solvent. In the second study, the effects of a single, high, oral dose of $2.5 \mathrm{mg} / \mathrm{kg}$ prucalopride were assessed $(n=9$; weight 9.0-13.0 kg; varying ages). In the third study, dogs ( $n=7$; weight $11.0-12.0 \mathrm{~kg}$; varying ages) were intravenously administered control or increasing doses of prucalopride: $0.02,0.04,0.08,0.16$, and $0.31 \mathrm{mg} / \mathrm{kg}$. The parameters measured were the same as those described for anesthetized dogs. Changes in behavior were also recorded throughout the experiment. Differences between control-treated groups and prucalopride-treated groups of less than $10 \%$ of the median peak values were considered to be of no physiological relevance, even if they were statistically significant. Data were analyzed using the Mann-Whitney $U$ test. Methodological details are provided in Supplemental Information 11.

\section{5-HT 4 Receptor-Mediated Cardiovascular Pharmacology}

In vitro and in vivo studies were conducted to evaluate the potential of prucalopride to elicit adverse cardiovascular effects via interaction with cardiac $5-\mathrm{HT}_{4}$ receptors. As only humans, pigs, and monkeys have functional cardiac $5-\mathrm{HT}_{4}$ receptors under physiological conditions (De Maeyer et al., 2008), studies were restricted to pigs and humans.

\section{In Vitro Studies}

Chronotropic and Inotropic Effects of Prucalopride in Piglet and Human Atrial Myocardium. The chronotropic effects of prucalopride and cisapride $1 \mathrm{nM}-10 \mu \mathrm{M}$ were evaluated in spontaneously beating right atria from newborn piglets (five males; 1- to 2-days-old). The inotropic effects of prucalopride and cisapride were evaluated in halved left atria from newborn piglets and in freshly obtained right atrial samples from 13 patients undergoing coronary artery bypass surgery [ 12 men, mean age $56 \pm 4$ years (range 43-76 years); one woman, aged 71 years]. All patients were treated with $\beta$-blockers, and none of them had been diagnosed with heart failure. The chronotropic and inotropic potencies of prucalopride and cisapride were expressed as a percentage of the maximum effect induced by 5-HT 200-600 $\mu \mathrm{M}$ or (-)-isoprenaline 200-600 $\mu \mathrm{M}$, and CRCs were constructed. In addition, to evaluate the potential of prucalopride $10 \mu \mathrm{M}$ or cisapride $10 \mu \mathrm{M}$ to antagonize the effects induced by 5 -HT, a cumulative CRC for 5-HT was constructed in both the absence and presence of both agonists. Identical experiments were also performed in human atrial tissue that was preincubated for 90 minutes with the 
selective $5-\mathrm{HT}_{4}$ receptor antagonist GR113808 (1 $\left.\mu \mathrm{M}\right)$. Methodological details are described in Supplemental Information 12.

\section{In Vivo Studies}

Cardiovascular Parameters in Anesthetized Juvenile Pigs. Cardio-hemodynamic, cardio-electrophysiological, and pulmonary parameters in response to prucalopride were evaluated in anesthetized juvenile pigs ( $n=6-10$ per dose group; weight $13.2-19.0 \mathrm{~kg}$ ). Pigs were intravenously administered control (water), or prucalopride at 30 -minute intervals according to a low-dose $(0.02,0.04,0.08$, and $0.16 \mathrm{mg} / \mathrm{kg}$; total dose $0.30 \mathrm{mg} / \mathrm{kg})$, or high-dose $(0.16,0.32,0.63$, and $1.25 \mathrm{mg} / \mathrm{kg}$; total dose $2.36 \mathrm{mg} / \mathrm{kg}$ ) protocol. The following parameters were measured: various time intervals of the ECG [PQ, QRS, QT, QTc (Bazett, Fredericia and Van de Water corrections)], heart rate, aortic blood pressure, pulmonary artery blood pressure, LVEDP, $\mathrm{LVdP} / \mathrm{dt}_{\max }, \mathrm{LVdP} / \mathrm{dt}_{\text {min }}$, contractility index, pressure-rate product, cardiac output, stroke volume, the index of relaxation, and systemic and pulmonary vascular resistance. Differences between controltreated groups and prucalopride-treated groups of less than $10 \%$ of the median peak values were considered to be of no physiological relevance, even if they were statistically significant. Data were analyzed using the Mann-Whitney $U$ test. Methodological details are provided in Supplemental Information 10.

\section{Chronic Toxicology Studies in Rats and Dogs}

Prucalopride is indicated for the treatment of chronic constipation; patients are recommended to receive a daily dose of $2 \mathrm{mg}$. The effects of repeated high doses of prucalopride on the cardiovascular system were evaluated as part of a set of chronic toxicology studies.

Repeated Dose Toxicity Studies in Rats and Dogs. The effect of repeated high doses of prucalopride on heart weight and cardiac histology were investigated in healthy Wistar rats [substrain Hannover; $n=200$ (100 male, 100 female); $4-5$ weeks old]. Prucalopride was administered daily by oral gavage over a 6 -month period, which was followed by a 1-month recovery period. Doses given were 5, 20, and $80 \mathrm{mg} / \mathrm{kg}$ body weight per day. Additional methodological details are provided in Supplemental Information 13.

The effect of repeated high doses of prucalopride on the following parameters was also investigated in healthy Beagle dogs $[n=32$ (16 male, 16 female); 6-7 months old]: ECG, heart rate, blood pressure, heart weight, and cardiac histology. Prucalopride was administered daily by oral gavage over a 12-month period. Doses given were 2.5, 10 and $30 \mathrm{mg} / \mathrm{kg}$ body weight per day Additional methodological details are provided in Supplemental Information 14.

\section{Results}

\section{Non-5- $\mathrm{HT}_{4}$ Receptor-Mediated Cardiovascular Pharmacology In Vitro Studies}

Effect of Prucalopride on Electrophysiological Parameters in Guinea Pig, Rabbit, and Human Cells and Tissues.

hERG-Transfected HEK293 Cells. Prucalopride at concentrations up to $1 \mu \mathrm{M}(370 \mathrm{ng} / \mathrm{ml}$; approximately 50 times the human therapeutic $\mathrm{C}_{\max }$ ) had no effect on the hERG current (less than 15\% inhibition). At prucalopride concentrations of 3-100 $\mu \mathrm{M}$ (exceeding therapeutic plasma concentrations in man), concentration-dependent inhibition of the current was observed (Fig. 2). The $\mathrm{IC}_{50}$ of prucalopride was $11-22 \mu \mathrm{M}$ (550-1100 times the human therapeutic $\mathrm{C}_{\max }$ ). This inhibition was reversible after 5 minutes in the absence of prucalopride. In addition, there was no evidence of Loewe additivity (Loewe, 1953) or Bliss independence (Bliss, 1939) following
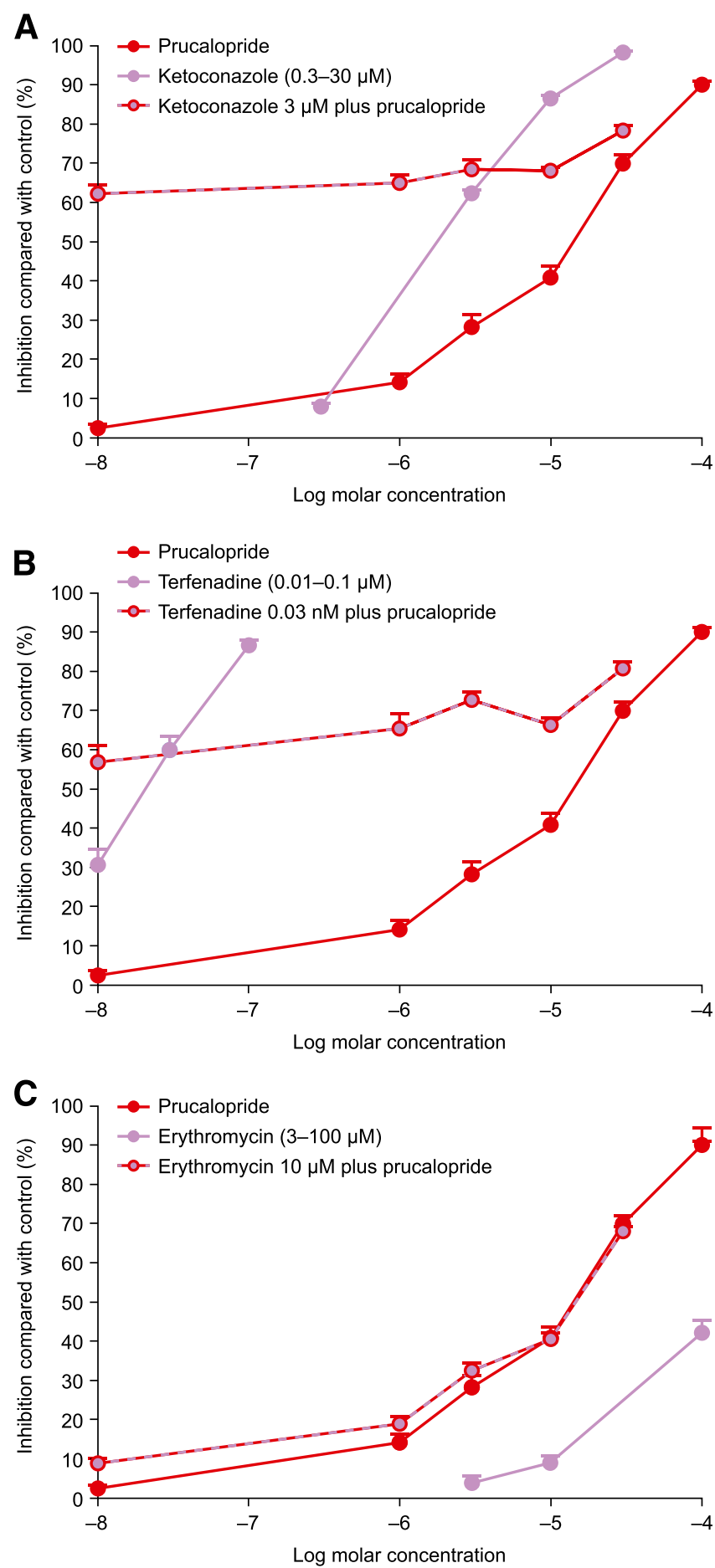

Fig. 2. Effects of prucalopride $(n=8-9)$ alone and combined with (A) ketoconazole $(n=8)$, (B) terfenadine $(n=8)$, and (C) erythromycin $(n=8)$ on inhibition of the hERG potassium current $\left(I_{\mathrm{Kr}}\right)$ in $h E R G$-transfected HEK293 cells. Data are mean \pm S.E.M.

coadministration of prucalopride with ketoconazole $(3 \mu \mathrm{M})$, terfenadine (0.03 $\mu \mathrm{M})$, or erythromycin (10 $\mu \mathrm{M}$; Fig. 2).

Guinea Pig Ventricular Myocytes. Prucalopride did not affect the two components of the delayed rectifier and inward rectifier potassium currents, the fast sodium current, or the L-type calcium current at concentrations up to $1 \mu \mathrm{M}$ (50 times the human therapeutic $\mathrm{C}_{\text {max }}$; data not shown). At a concentration of $10 \mu \mathrm{M}$ (500 times the human therapeutic $\mathrm{C}_{\max }$ ), 
prucalopride inhibited the rapidly activating component of the delayed rectifier potassium current by $61 \%$, whereas the other ion channels were not affected (data not shown).

Isolated Rabbit and Dog Purkinje Fibers. Prucalopride $1 \mu \mathrm{M}$ $\left(370 \mathrm{ng} / \mathrm{ml} ; 50\right.$ times the human therapeutic $\mathrm{C}_{\max }$ ) had no effect on any of the electrophysiological parameters measured in rabbit Purkinje fibers (Supplemental Table 1) under either normal rhythm conditions $(1 \mathrm{~Hz})$ or conditions mimicking extreme bradycardia $(0.2 \mathrm{~Hz})$. At higher concentrations of 3 and $10 \mu \mathrm{M}$ (approximately 150 and 500 times the human therapeutic $\mathrm{C}_{\max }$, respectively) and under normal rhythm conditions, prucalopride induced a concentration-dependent prolongation of $\mathrm{APD}_{90}(+22 \%$ and $+48 \%$, respectively), the $\operatorname{ERP}(+17 \%$ and $+39 \%$, respectively), and RT $(+18 \%$ and $+40 \%$, respectively) but did not induce early or delayed afterdepolarizations, either at normal or at bradycardic rates of stimulation (data not shown).

In canine Purkinje fibers, under conditions of normokalemia $(\mathrm{KCl} 4 \mathrm{mM})$ and at a normal rate of stimulation $(1 \mathrm{~Hz})$, prucalopride had no effect on electrophysiological parameters at concentrations up to $1 \mu \mathrm{M}$ (50 times the human therapeutic $\mathrm{C}_{\max }$ ). Prucalopride $10 \mu \mathrm{M}$ (500 times the human therapeutic $\left.\mathrm{C}_{\max }\right)$ caused a $14 \%, 10 \%$ and $16 \%$ increase in $\mathrm{APD}_{90}, \mathrm{ERP}$ and RT, respectively, compared with solvent $(P<0.05)$; no other effects on electrophysiological parameters were observed (Supplemental Table 2). In addition, prucalopride did not induce early or delayed after-depolarizations (Supplemental Table 2).

Guinea Pig Isolated Papillary Muscle. Under normokalemic conditions ( $\mathrm{KCl} 4 \mathrm{mM}$ ) and a normal rate of stimulation (1 Hz), prucalopride at concentrations of $0.1-1 \mu \mathrm{M}$ had no effect on electrophysiological parameters or contractile force. The only effect observed was a minor prolongation (7\%) of $\mathrm{APD}_{50}$ and $\mathrm{APD}_{90}$ at $1 \mu \mathrm{M}$ (approximately 50 times the human therapeutic $\mathrm{C}_{\max }$ ). At the highest tested concentration of $10 \mu \mathrm{M}$ (approximately 500 times the human therapeutic $\left.\mathrm{C}_{\max }\right)$, prucalopride slightly prolonged $\mathrm{APD}_{50}(+13 \%)$ and $\mathrm{APD}_{90}(+14 \%)$ compared with baseline values but did not affect any other parameters of the action potential (AAP, RMP, $V_{\max }$ ) or contractile force (Table 1). Similar results were obtained under conditions of normokalemia and bradycardia, and under hypokalemia and a normal rate of stimulation, where prucalopride $10 \mu \mathrm{M}$ caused increases in $\mathrm{APD}_{90}$ of $18 \%$ and $22 \%$, respectively, relative to solvent (data not shown).

Isolated Rabbit Heart. Prucalopride had no relevant effect on coronary perfusion, automaticity and escape cycle lengths, excitability, or conduction at concentrations up to $10 \mu \mathrm{M}$ (500 times the therapeutic $\mathrm{C}_{\max }$ in man; data not shown). At concentrations above $3 \mu \mathrm{M}$ (at least 150 times the therapeutic $\mathrm{C}_{\max }$ in man) prucalopride prolonged the APD (Supplemental Fig. 1), slowed repolarization, and induced instability and reverse-use dependency. At the highest concentration tested $(10 \mu \mathrm{M})$, a slight and nonsignificant prolongation of $\mathrm{APD}_{90}$ was observed (from $314 \pm 15$ milliseconds with control to $337 \pm 33$ milliseconds; $P>0.05$ ). No proarrhythmic activity was induced at any dose tested (data not shown). In a subsequent study, prucalopride, alone or in combination with ketoconazole or erythromycin, had no relevant electrophysiological effects at concentrations up to $1 \mu \mathrm{M}$ (50 times the human therapeutic $\mathrm{C}_{\max }$ ). At concentrations of $3 \mu \mathrm{M}$, prucalopride elicited prolongation of the APD with a trend toward triangulation. However, this prolongation was not observed in the presence of ketoconazole or erythromycin, whereas some triangulation was observed in the presence of erythromycin (data not shown).

Platelet Aggregation. Platelet aggregation responses to ADP and TRAP were significantly enhanced $(P<0.0001)$ in the presence of thrombopoietin [positive control $(100 \mathrm{ng} / \mathrm{ml}$; Fig. 3)]. No comparable effects on platelet aggregation were observed in the presence of prucalopride (at 1, 3, and 10 times the human therapeutic $\mathrm{C}_{\max }$ ), tegaserod, or 5-HT, compared with vehicle. In the antagonist studies, aggregation responses to a combination of epinephrine plus 5-HT were partially inhibited by the $5-\mathrm{HT}_{2 \mathrm{~A}}$ receptor-specific antagonist ketanserin $(P=0.0023$ vs. control), whereas no inhibition was observed with the $5-\mathrm{HT}_{4}$ receptor antagonist SDZ 205-557 (Fig. 3).

Coronary Artery Contractility. In isolated canine, porcine, and human coronary arteries, the application of $5-\mathrm{HT}(30 \mathrm{nM}-10 \mu \mathrm{M})$ resulted in a significant concentration-dependent increase in contractility $(P<0.001$; Fig. 4$)$. In contrast, prucalopride $1 \mathrm{nM}-10 \mu \mathrm{M}$ (up to 500 times the human therapeutic $\mathrm{C}_{\max }$ ) did not elicit any contractile responses. No significant contractile responses were observed following tegaserod application $(\leq 10 \mu \mathrm{M})$ in porcine or human arteries; however, significant increases in contractile responses were observed in canine arteries at tegaserod concentrations of 3 and $10 \mu \mathrm{M}$ $(P<0.001$; Fig. 4).

\section{In Vivo Studies.}

Cardiovascular Effects of Prucalopride in Anesthetized Rabbits and Guinea Pigs. In the methoxamine-challenged rabbit model, treatment with prucalopride $(0.04$ or $0.08 \mathrm{mg} / \mathrm{kg}$

TABLE 1

Electrophysiological effects of prucalopride in isolated guinea pig papillary muscle

Stimulations were performed under normal rhythm conditions $(1 \mathrm{~Hz})$ and normokalemia $(\mathrm{KCl} 4 \mathrm{mM})$. Values are mean $\pm \mathrm{S} . \mathrm{E}$.

\begin{tabular}{|c|c|c|c|c|c|c|c|c|c|c|}
\hline \multirow{2}{*}{ Parameter } & \multicolumn{5}{|c|}{ Vehicle $(\mathrm{n}=6)$} & \multicolumn{5}{|c|}{ Prucalopride $(\mu \mathrm{M} ; \mathrm{n}=8)$} \\
\hline & Baseline & First & Second & Third & Fourth & Baseline & 0.01 & 0.1 & 1 & 10 \\
\hline $\mathrm{AAP}(\mathrm{mV})$ & $127 \pm 2$ & $124 \pm 3$ & $126 \pm 2$ & $129 \pm 2$ & $131 \pm 2$ & $127 \pm 2$ & $126 \pm 3$ & $127 \pm 2$ & $128 \pm 2$ & $126 \pm 3$ \\
\hline $\mathrm{APD}_{90}(\mathrm{~ms})$ & $176 \pm 5$ & $181 \pm 5^{a}$ & $183 \pm 6^{a}$ & $180 \pm 6$ & $181 \pm 6^{a}$ & $176 \pm 6$ & $177 \pm 6$ & $178 \pm 8$ & $188 \pm 7^{a}$ & $201 \pm 6^{a}$ \\
\hline $\mathrm{APD}_{50}(\mathrm{~ms})$ & $152 \pm 5$ & $158 \pm 5^{a}$ & $160 \pm 5^{a}$ & $157 \pm 6$ & $157 \pm 6^{a}$ & $154 \pm 5$ & $154 \pm 6$ & $156 \pm 7$ & $165 \pm 6^{a}$ & $174 \pm 5^{a}$ \\
\hline $\mathrm{RMP}(\mathrm{mV})$ & $92 \pm 2$ & $89 \pm 2$ & $91 \pm 1$ & $90 \pm 1$ & $90 \pm 2$ & $90 \pm 1$ & $88 \pm 2$ & $88 \pm 2$ & $90 \pm 1$ & $88 \pm 2$ \\
\hline $\mathrm{V}_{\max }(\mathrm{V} / \mathrm{s})$ & $200 \pm 4$ & $189 \pm 6$ & $206 \pm 8$ & $193 \pm 9$ & $211 \pm 16$ & $218 \pm 14$ & $216 \pm 7^{b}$ & $218 \pm 9$ & $219 \pm 11$ & $221 \pm 6$ \\
\hline $\mathrm{CF}(\mathrm{MN})$ & $1.54 \pm 0.39$ & $1.56 \pm 0.40$ & $1.52 \pm 0.40$ & $1.47 \pm 0.40$ & $1.40 \pm 0.41^{a}$ & $1.41 \pm 0.22$ & $1.43 \pm 0.22$ & $1.37 \pm 0.26$ & $1.46 \pm 0.24$ & $1.34 \pm 0.23$ \\
\hline
\end{tabular}

$\mathrm{AAP}$, amplitude of resting action potential; $\mathrm{APD}_{90}$, action potential duration at $90 \%$ repolarization; $\mathrm{APD} \mathrm{D}_{50}$, action potential duration at $50 \%$ repolarization; $\mathrm{CF}$, contractile force; RMP, resting membrane potential; $\mathrm{V}_{\max }$, maximum rate of depolarization during the upstroke.

${ }^{a} P \leq 0.05$ vs. own baseline value.

${ }^{b} P \leq 0.05$ vs. vehicle. 

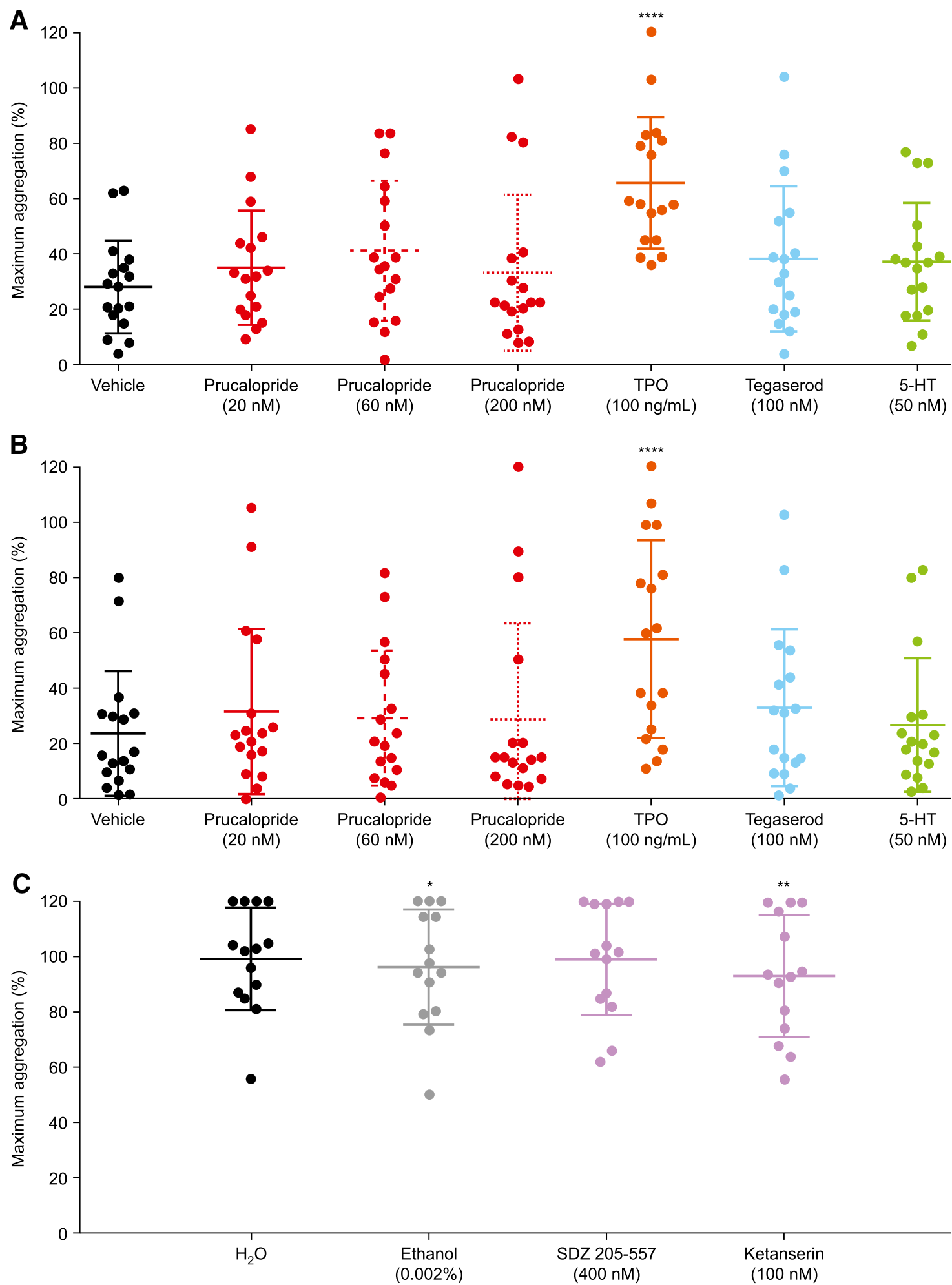

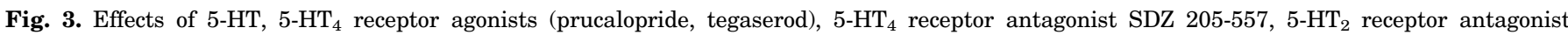
(ketanserin), and vehicle on platelet aggregation responses. Platelet aggregation was induced by (A) ADP (1.5 $\mu \mathrm{M})$, (B) TRAP (1 $\mu \mathrm{M})$, and (C) 5-HT $(0.5 \mu \mathrm{M})$ plus epinephrine $(2.5 \mu \mathrm{M})$ following incubation with agonists $(\mathrm{A}$ and $\mathrm{B})$ or antagonists $(\mathrm{C})$. Data points are maximum aggregation responses, and the data are shown as mean (central horizontal line) \pm S.D. (bars). $N=17$ for A-C. $* P<0.05 ; * * P<0.01 ; * * * P<0.0001$ vs. vehicle (water). 5 -HT, 5-hydroxytryptamine; TPO, thrombopoietin; TRAP, thrombin receptor activating peptide.

per minute for 60 minutes; total doses of 2.4 and $4.8 \mathrm{mg} / \mathrm{kg}$, respectively) had no significant effect on heart rate, mean arterial pressure, or ECG parameters compared with control (Table 2). At these doses, the mean peak plasma concentrations were $389 \pm 56$ and $1135 \pm 124 \mathrm{ng} / \mathrm{ml}$, respectively, corresponding to 52 and 152 times the human therapeutic $\mathrm{C}_{\max }$. At high doses of 9.6 and $18.6 \mathrm{mg} / \mathrm{kg}$ (corresponding mean plasma concentrations $2654 \pm 222$ and 
A
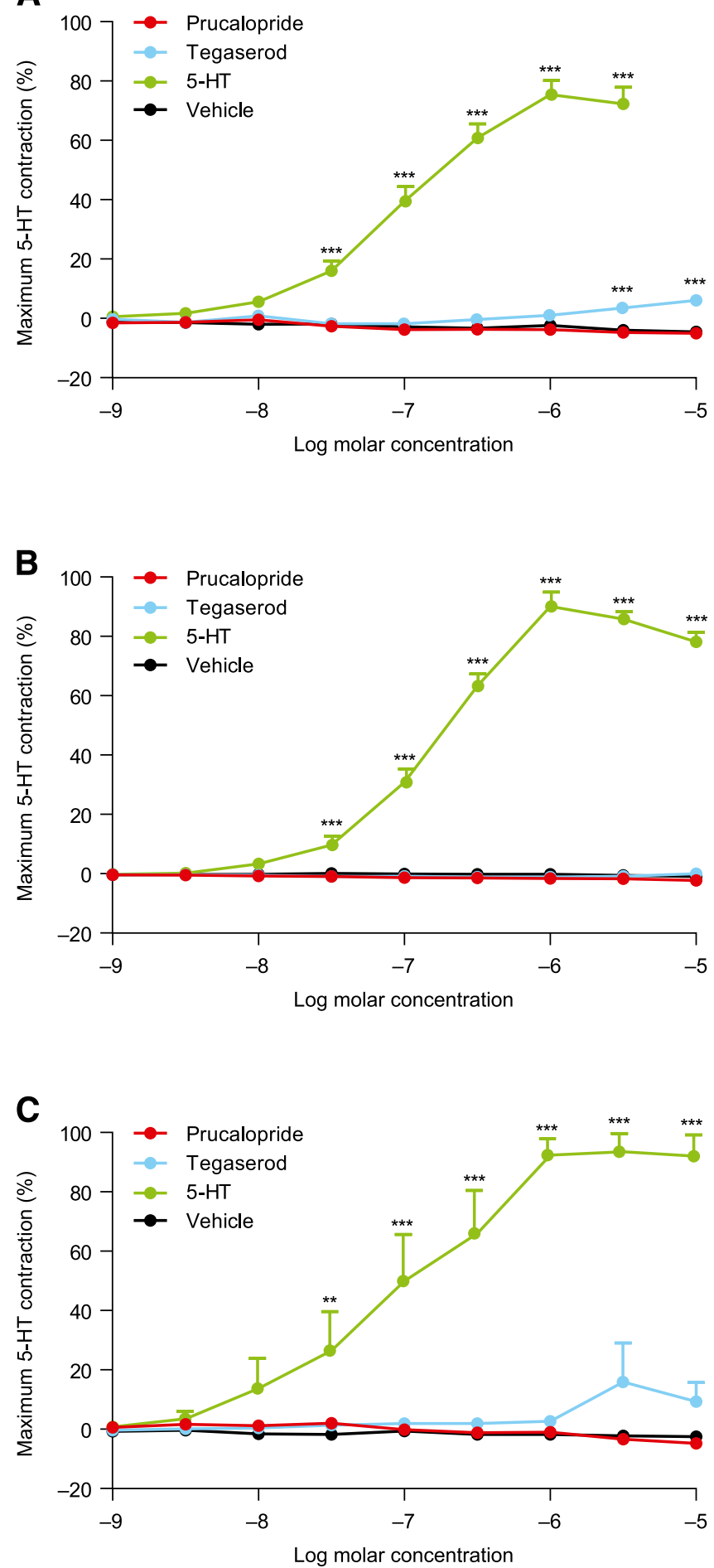

Fig. 4. Effects of prucalopride, tegaserod, 5-HT, and vehicle measured in isolated left anterior descending coronary arteries. Contractile responses were evaluated in (A) canine $(n=5),(\mathrm{B})$ porcine $(n=5)$, and (C) human $(n=5)$ coronary arteries. Cumulative concentration-response curves were constructed for prucalopride ( $1 \mathrm{nM}-10 \mu \mathrm{M})$, tegaserod $(1 \mathrm{nM}-10 \mu \mathrm{M}), 5-\mathrm{HT}$ $(1 \mathrm{nM}-10 \mu \mathrm{M})$, and vehicle. Data are expressed as a percentage of the contraction elicited by the maximum priming dose of 5-HT $\left(3 \times 10^{-6} \mathrm{M}\right)$. Data are mean + S.E.M. Each concentration was applied following the peak of the contraction or following an exposure of at least 5 minutes. ** $P<0.05$; *** $P<0.001$. 5-HT, 5-hydroxytryptamine.
$4812 \pm 485 \mathrm{ng} / \mathrm{ml}$, respectively; 354 and 642 times the human therapeutic $\mathrm{C}_{\max }$ ), prucalopride did not significantly affect heart rate, blood pressure, the amplitude of the $P$ and $R$ waves, or dispersion of the QT and QTc intervals but significantly increased the QT, QTc, JT, and JTc intervals compared with control $(P<0.05$; Table 2). Slight but significant increases in PR interval and QRS duration were observed at a prucalopride dose of $9.6 \mathrm{mg} / \mathrm{kg}$ (corresponding plasma concentration $2654 \pm 222 \mathrm{ng} / \mathrm{ml} ; P<0.05$ vs. control). QRS duration was also slightly increased at the highest dose of $18.6 \mathrm{mg} / \mathrm{kg}$ $(P<0.05$ vs. control). Prucalopride did not induce any cardiac arrhythmias such as cardiac conduction disturbances, atrioventricular (AV) block, ventricular premature beats, polymorphic ventricular tachycardia, torsade de pointes, ventricular fibrillation or death at doses up to $18.6 \mathrm{mg} / \mathrm{kg}(4812 \mathrm{ng} / \mathrm{ml}$; 642 times the human therapeutic $\mathrm{C}_{\max }$ ).

In anesthetized guinea pigs, prucalopride $1.25 \mathrm{mg} / \mathrm{kg}$ (5-minute exposure) had no effect on heart rate, $\mathrm{PQ}$ or QRS duration, QT or Bazett-corrected QT intervals, and did not elicit cardiac conduction disturbances or arrhythmias. A small increase in mean arterial blood pressure (10-11\%) was noted at 5 and 20 minutes after the onset of the infusion but not at 10 and 30 minutes (data not shown). The $\mathrm{C}_{\max }$ reached at 30 minutes was $137 \mathrm{ng} / \mathrm{ml}$, corresponding to 18 times the human therapeutic $\mathrm{C}_{\max }$.

In a second study, limited effects on heart rate were observed at prucalopride doses of $5 \mathrm{mg} / \mathrm{kg}$ or higher over a period of 5 minutes. A transient and slight decrease in heart rate was observed 5 minutes after prucalopride infusion ( $-9 \%$ vs. $-4 \%$ with water). At a dose of $10 \mathrm{mg} / \mathrm{kg}$, effects on heart rate persisted at 30 minutes after infusion (maximum effect seen after 5 minutes; $-17 \%$ vs. $-4 \%$ with water) (data not shown). No effects on mean arterial blood pressure were observed at high doses of prucalopride ( 5 and $10 \mathrm{mg} / \mathrm{kg}$ ), although slight increases $(<10 \%)$ were observed at supratherapeutic doses of $1.25 \mathrm{mg} / \mathrm{kg}(+26 \%$ vs. $+17 \%$ with water) and $2.5 \mathrm{mg} / \mathrm{kg}(+22 \%$ vs. $+17 \%$ with water $) 5$ minutes after infusion (data not shown). At $1.25 \mathrm{mg} / \mathrm{kg}$ (corresponding peak plasma level $332 \mathrm{ng} / \mathrm{ml} ; 44$ times the human therapeutic $\mathrm{C}_{\max }$ ), prucalopride did not significantly affect ECG intervals. No effect on QRS duration was observed at any dose. Doses of $2.5,5$, and $10 \mathrm{mg} / \mathrm{kg}$ slightly but significantly increased the QTc interval $(+8 \%,+9 \%$ and $+13 \%$, respectively vs. $+1 \%$ with water) (data not shown). At dose levels up to $5 \mathrm{mg} / \mathrm{kg}$, prucalopride did not cause cardiac rhythm disturbances such as AV blocks, ventricular premature beats, ventricular tachycardia, torsade de pointes, or ventricular fibrillation. At $10 \mathrm{mg} / \mathrm{kg}$, AV block was observed in one out of 13 animals. After 5 minutes' infusion of $2.5,5$, and $10 \mathrm{mg} / \mathrm{kg}$, peak plasma concentrations of 714,1325 , and $3286 \mathrm{ng} / \mathrm{ml}$ were achieved, respectively, corresponding to 95,177 , and 438 times the human $\mathrm{C}_{\max }$.

Cardiovascular Effects of Prucalopride on Anesthetized Dogs. In anesthetized dogs, increasing intravenous doses of prucalopride from $0.02-1.25 \mathrm{mg} / \mathrm{kg}$ (total cumulative dose $2.5 \mathrm{mg} / \mathrm{kg}$; corresponding peak plasma concentration $1002 \mathrm{ng} / \mathrm{ml} ; 134$ times the therapeutic $\mathrm{C}_{\max }$ in man) had no significant effect on heart rate, ECG characteristics (PQ and QRS duration, QT, and QTc intervals), blood pressures, or pulmonary functional parameters (dynamic lung compliance, airway resistance), relative to control (data not shown).

In a second study, prucalopride enhanced left ventricular contractility and relaxation at doses of $0.63 \mathrm{mg} / \mathrm{kg}$ or higher. The peak plasma concentration at $0.63 \mathrm{mg} / \mathrm{kg}$ was $293 \mathrm{ng} / \mathrm{ml}$, 
TABLE 2

Effect of prucalopride on cardiovascular parameters in anesthetized rabbits $(n=7)$ during methoxamine administration Values are mean \pm S.E.M. All prucalopride concentrations tested resulted in plasma concentrations that exceeded therapeutic concentrations in man.

\begin{tabular}{|c|c|c|c|c|c|}
\hline \multirow{2}{*}{ Parameter } & \multirow{2}{*}{$\begin{array}{c}\text { Water }(\mathrm{ml} / \mathrm{kg} \text { per minute for } 60 \text { minutes }) \\
0.125\end{array}$} & \multicolumn{4}{|c|}{ Prucalopride (mg/kg per minute for 60 minutes) } \\
\hline & & 0.04 & 0.08 & 0.16 & 0.31 \\
\hline HR (beats/min) & $188 \pm 9$ & $215 \pm 13$ & $181 \pm 8$ & $166 \pm 12$ & $179 \pm 11$ \\
\hline MAP (mmHg) & $63 \pm 8$ & $70 \pm 7$ & $60 \pm 3$ & $49 \pm 3$ & $47 \pm 5$ \\
\hline PR-interval (ms) & $90 \pm 4$ & $90 \pm 3$ & $92 \pm 2$ & $106 \pm 5^{*}$ & $97 \pm 3$ \\
\hline QRS duration (ms) & $32 \pm 1$ & $32 \pm 2$ & $36 \pm 2$ & $39 \pm 2 *$ & $39 \pm 2^{*}$ \\
\hline Amplitude of $\mathrm{P}$ wave $(\mathrm{mV})$ & $0.13 \pm 0.01$ & $0.13 \pm 0.01$ & $0.1 \pm 0.01$ & $0.09 \pm 0.02$ & $0.10 \pm 0.01$ \\
\hline Amplitude of $\mathrm{R}$ wave (mV) & $0.62 \pm 0.06$ & $0.52 \pm 0.07$ & $0.62 \pm 0.09$ & $0.56 \pm 0.05$ & $0.61 \pm 0.08$ \\
\hline QT interval $(\mathrm{ms})$ & $198 \pm 10$ & $180 \pm 12$ & $218 \pm 8$ & $294 \pm 25^{*}$ & $291 \pm 22 *$ \\
\hline JT interval (ms) & $166 \pm 9$ & $147 \pm 11$ & $181 \pm 8$ & $255 \pm 24^{*}$ & $251 \pm 21^{*}$ \\
\hline QTc interval (ms) & $348 \pm 12$ & $336 \pm 14$ & $377 \pm 10$ & $481 \pm 26^{*}$ & $493 \pm 23^{*}$ \\
\hline JTc interval (ms) & $291 \pm 12$ & $274 \pm 14$ & $313 \pm 11$ & $416 \pm 26^{*}$ & $426 \pm 23^{*}$ \\
\hline QT dispersion (ms) & $10 \pm 4$ & $14 \pm 4$ & $12 \pm 3$ & $11 \pm 1$ & $15 \pm 2$ \\
\hline QTc dispersion (ms) & $18 \pm 6$ & $26 \pm 7$ & $20 \pm 2$ & $17 \pm 2$ & $25 \pm 3$ \\
\hline
\end{tabular}

$\mathrm{HR}$, heart rate; MAP, mean arterial pressure.

$* P<0.05$ vs. solvent (water).

corresponding to 39 times the human therapeutic $\mathrm{C}_{\max }$. Prucalopride had no relevant effect on blood pressure and other hemodynamic variables, cardio-electrophysiologic parameters (PQ and QRS durations, QT, and QTc intervals) or pulmonary parameters (oxygen saturation difference, peak inspiration pressure and flow, expiratory airway resistance, dynamic lung compliance, work of breathing) at doses of $0.63-5 \mathrm{mg} / \mathrm{kg}$ (total dose, $9.38 \mathrm{mg} / \mathrm{kg}$; peak plasma levels of $3793 \mathrm{ng} / \mathrm{ml}$, at least 500 times the human therapeutic $\mathrm{C}_{\max }$ ). At $2.5 \mathrm{mg} / \mathrm{kg}$ modest increases in heart rate and cardiac output were observed (data not shown). At doses up to $2.5 \mathrm{mg} / \mathrm{kg}$, the action potential duration at $70 \%$ repolarization $\left(\mathrm{APD}_{70}\right)$ and $\mathrm{APD}_{90}$, and $\mathrm{APD}_{90}$ corrected for changes in heart rate, were not affected. At a dose of $5 \mathrm{mg} / \mathrm{kg}$, these parameters and the QT interval were slightly shortened. No cardiac rhythm disturbances (such as early or delayed afterdepolarizations) were observed at any dose tested.

Cardiovascular Effects of Prucalopride in Conscious Dogs. In instrumented, freely moving, conscious dogs, a single, low, oral dose of $0.31 \mathrm{mg} / \mathrm{kg}$ prucalopride had no relevant, consistent effects on cardiovascular parameters (blood pressure, cardiac contractility and relaxation, cardiac output, stroke volume, total systemic resistance, coronary artery flow, ECG intervals, and heart rate) monitored for 240 minutes after dosing (data not shown). Prucalopride also had no effect on behavioral parameters. The maximum plasma level achieved at 60 minutes after administration was $61 \mathrm{ng} / \mathrm{ml}$ (eight times the human therapeutic $\mathrm{C}_{\max }$ ).

In the second study, a single, high oral dose of $2.5 \mathrm{mg} / \mathrm{kg}$ prucalopride induced an increase in heart rate, diastolic and systolic blood pressure, pressure rate product, $\mathrm{LVdp} / \mathrm{dt}_{\max }$, $\mathrm{LVdp} / \mathrm{dt}_{\text {min, }}$, contractility index, and cardiac output (median peak effect: $+30 \%,+34 \%,+29 \%,+55 \%,+39 \%,+18 \%,+37 \%$, $+40 \%$ respectively), compared with control (data not shown). Plasma levels measured at 30, 60, and 240 minutes after dosing were 670,505 , and $310 \mathrm{ng} / \mathrm{ml}$, respectively, exceeding the human therapeutic $\mathrm{C}_{\max }$ by 89,67 , and 41 times. Compared with control, this high dose of prucalopride had no relevant, consistent effects on the relaxation time constant, stroke volume, total systemic resistance, or the duration of the QRS, QT, and QTc intervals, monitored for 240 minutes after dosing (data not shown). No effect of prucalopride was noted on the duration of the PQ interval with manual analysis of the ECG; however, a computerized analysis showed a slight trend for a reduction in $\mathrm{PQ}$ interval $(\sim 10 \%)$, secondary to the increase in heart rate observed during the post-dosing period. A short period of extrasystole was observed in two dogs from the control group; this was not observed in the prucalopridetreated group. No changes in behavior were noted in eight out of nine dogs in the control group and in nine out of nine dogs in the prucalopride-treated group (data not shown).

In comparison with control, prucalopride $(0.02-0.31 \mathrm{mg} / \mathrm{kg}$ dosed intravenously; total dose $0.61 \mathrm{mg} / \mathrm{kg}$ ) induced no biologically relevant effects on heart rate, cardiac output, stroke volume, coronary blood flow, or ECG parameters that consistently exceeded $10 \%$ change vs. baseline (data not shown). The plasma level 5 minutes after administration of $0.31 \mathrm{mg} / \mathrm{kg}$ was $174 \mathrm{ng} / \mathrm{ml}$, corresponding to 23 times the human therapeutic $\mathrm{C}_{\max }$.

Prucalopride induced a dose-dependent increase in systolic blood pressure, which reached statistical significance compared with control at a dose of $0.04 \mathrm{mg} / \mathrm{kg}$ (median peak values $+12 \%,+21 \%,+25 \%$, and $+28 \%$ from baseline after doses of $0.04,0.08,0.16$, and $0.31 \mathrm{mg} / \mathrm{kg}$, respectively), and in diastolic blood pressure, which reached statistical significance compared with control at $0.08 \mathrm{mg} / \mathrm{kg}$ (median peak values $+39 \%$, $+46 \%$, and $+50 \%$ from baseline after doses of $0.08,0.16$, and $0.31 \mathrm{mg} / \mathrm{kg}$, respectively). The pressure rate product increased significantly following a prucalopride dose of $0.08 \mathrm{mg} / \mathrm{kg}$ (median peak value $+40 \%$ from baseline), and total systemic resistance increased significantly following a dose of $0.04 \mathrm{mg} / \mathrm{kg}$ (median peak value $+14 \%$ from baseline; data not shown). Plasma levels 5 minutes after intravenous administration of prucalopride 0.04 and $0.08 \mathrm{mg} / \mathrm{kg}$ were 15 and $36 \mathrm{ng} / \mathrm{ml}$, respectively, corresponding to two to five times the human therapeutic $\mathrm{C}_{\max }$. These effects were accompanied by one episode of vomiting.

No behavioral alterations were observed during or after treatment in the control group or in four of seven dogs in the prucalopride-treated group. Three dogs vomited immediately following administration of prucalopride $0.04 \mathrm{mg} / \mathrm{kg}$; one of these dogs also vomited following administration of prucalopride $0.08 \mathrm{mg} / \mathrm{kg}$.

\section{5- $\mathrm{HT}_{4}$ Receptor-Mediated Cardiovascular Pharmacology In Vitro Studies}

Chronotropic and Inotropic 5-HT 4 Receptor-Mediated Effects of Prucalopride on Piglet and Human Atrial Myocardium. In the paced human right atrium (inotropic 
effect; Fig. 5C) and in the spontaneously beating porcine right atrium (chronotropic effect; Fig. 5A), prucalopride behaved as a partial $5-\mathrm{HT}_{4}$ receptor agonist compared with 5-HT. A positive inotropic response was observed in porcine left atrium (Fig. 5B). In contrast, cisapride only minimally increased contractile force (Fig. 5D); however, both prucalopride and cisapride could antagonize the effects of 5-HT (Table 3).

GR113808 (a selective $5-\mathrm{HT}_{4}$ receptor antagonist) completely antagonized the chronotropic and inotropic effects of prucalopride, cisapride, and 5-HT, consistent with mediation through $5-\mathrm{HT}_{4}$ receptors, but did not antagonize the effects of (-)-isoprenaline (data not shown). No arrhythmic contractions were observed in these models after the administration of prucalopride up to $10 \mu \mathrm{M}$ (500 times the human therapeutic plasma level).

\section{In Vivo Studies}

Cardiovascular Effects of Prucalopride on Anesthetized Pigs. In anesthetized pigs that received the low-dose range, prucalopride induced slight and transient increases in heart rate and systolic and diastolic blood pressure at doses of $0.02 \mathrm{mg} / \mathrm{kg}$ (plasma level $6.7 \mathrm{ng} / \mathrm{ml}$ ) or higher.
The maximal effect on heart rate $(+22 \%$ from baseline vs. $-8 \%$ in the solvent group; increase of 14 beats $/ \mathrm{min}$ ) and pressure rate product $(+14 \%$ from baseline vs. $-10 \%$ with solvent) was observed at $0.16 \mathrm{mg} / \mathrm{kg}$ (maximum plasma concentration $79.8 \mathrm{ng} / \mathrm{ml}$, approximately 10 times the therapeutic $\mathrm{C}_{\max }$ in man) (Table 4). These responses faded over a 30-minute period and the subsequent administration of higher doses resulted in less pronounced effects.

The high-dose range of prucalopride [0.16-1.25 mg/kg; corresponding to median plasma concentrations of $70-757 \mathrm{ng} / \mathrm{ml}$, (10-100 times the therapeutic $\mathrm{C}_{\max }$ in man)], induced increases in heart rate (maximal effect after $0.16 \mathrm{mg} / \mathrm{kg}+19 \%$ from baseline vs. $-2 \%$ with solvent), diastolic aortic blood pressure (maximal effect after $0.16 \mathrm{mg} / \mathrm{kg}$ : $+18 \%$ from baseline vs. $0 \%$ with solvent), and pressure rate product (maximal effect after $0.32 \mathrm{mg} / \mathrm{kg}+32 \%$ from baseline vs. $-2 \%$ with solvent) (Table 4 ). High doses of prucalopride had no significant effect on LVEDP, $\mathrm{LVdP} / \mathrm{dt}_{\text {max }}, \mathrm{LVdP} / \mathrm{dt}_{\text {min }}$, stroke volume, cardiac output, or systemic or pulmonary vascular resistance $(P>0.05$ vs. control; Table 4). Prucalopride did not significantly affect the duration of the PQ interval, the QRS complex, and the QT and corrected QT intervals relative to solvent, at a cumulative dose of $2.36 \mathrm{mg} / \mathrm{kg}$ (approximately 100 times the therapeutic $\mathrm{C}_{\max }$ in man) (Table 4).
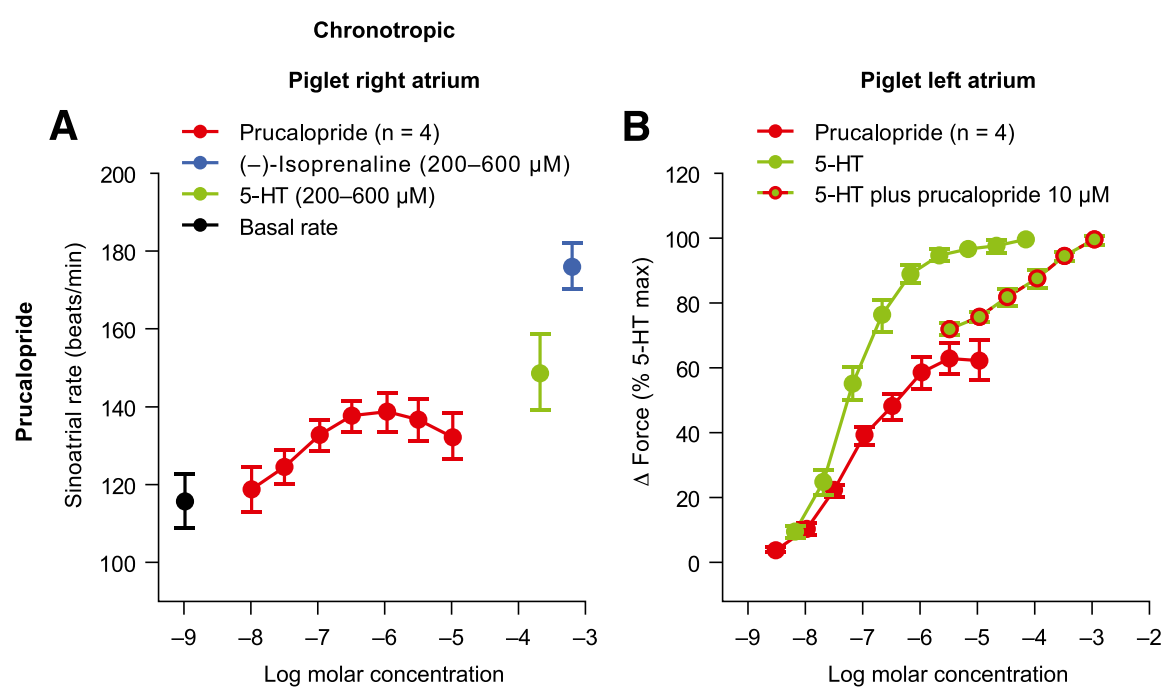

Inotropic
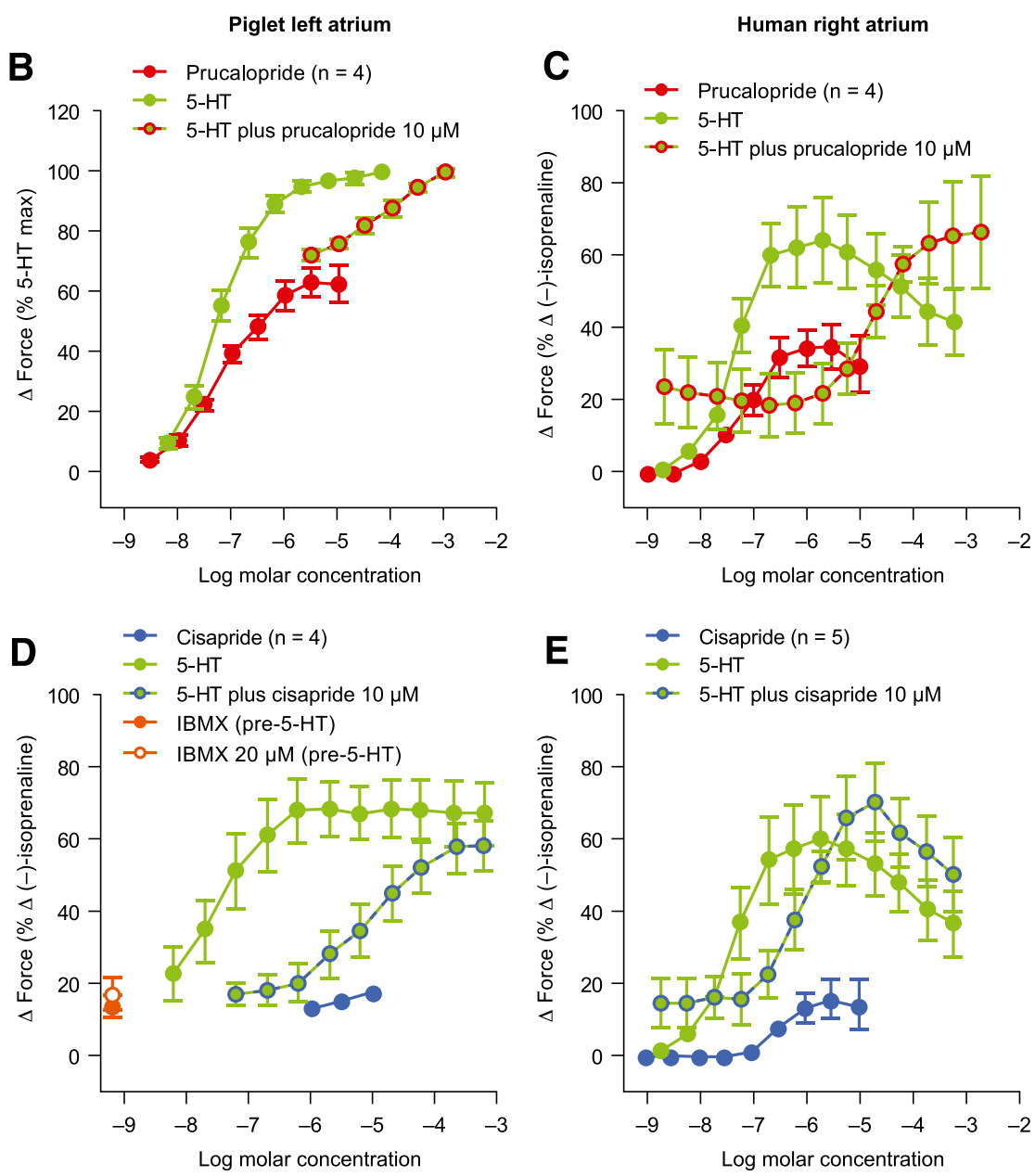

Fig. 5. Chronotropic (A) and inotropic effects of prucalopride (B and C) and cisapride (D and E) measured in piglet and human atrial myocardium. Cumulative concentration-response curves were determined for prucalopride and cisapride ( $1 \mathrm{nM}-10 \mu \mathrm{M})$, followed by administration of 5 -HT (200-600 $\mu \mathrm{M})$, and then (-)-isoprenaline (200-600 $\mu \mathrm{M})$. Data are mean + S.E.M. 5-HT, 5-hydroxytryptamine; IBMX, isobutylmethylxanthine. 
TABLE 3

Stimulant and blocking effects of partial agonists measured in piglet and human atrial myocardium Values are mean \pm S.E.

\begin{tabular}{|c|c|c|c|}
\hline \multirow[b]{2}{*}{ Agonist } & \multicolumn{2}{|c|}{ Piglet } & \multirow{2}{*}{$\frac{\text { Human }}{\begin{array}{c}\text { Right Atrium } \\
\text { Inotropic }\end{array}}$} \\
\hline & $\begin{array}{l}\text { Right Atrium } \\
\text { Chronotropic }\end{array}$ & $\begin{array}{l}\text { Left Atrium } \\
\text { Inotropic }\end{array}$ & \\
\hline Prucalopride & $n=5$ & $n=4$ & $n=4$ \\
\hline Stimulation potency $\left(-\log \mathrm{EC}_{50}, \mathrm{M}\right)$ & $7.35 \pm 0.25^{a}$ & $7.17 \pm 0.07^{a}$ & $7.09 \pm 0.12$ \\
\hline Intrinsic activity $^{b}$ & $0.72 \pm 0.11^{a}$ & $0.65 \pm 0.05^{a}$ & $0.51 \pm 0.09$ \\
\hline Blocking potency $\left(-\log \mathrm{K}_{\mathrm{p}}, \mathrm{M}\right)$ & & $7.09 \pm 0.21^{a}$ & $7.27 \pm 0.33$ \\
\hline Cisapride & $n=4$ & $n=4$ & $n=5$ \\
\hline Stimulation potency $\left(-\log \mathrm{EC}_{50}, \mathrm{M}\right)$ & $6.44 \pm 0.08^{c}$ & ND & $6.44 \pm 0.14$ \\
\hline Intrinsic activity $^{b}$ & $0.43 \pm 0.06^{c}$ & $0.09 \pm 0.02$ & $0.27 \pm 0.07$ \\
\hline Blocking potency $\left(-\log \mathrm{K}_{\mathrm{p}}, \mathrm{M}\right)$ & & $7.03 \pm 0.22$ & $6.15 \pm 0.31$ \\
\hline
\end{tabular}

No aberrant ECG complexes such as irregular RR interval, supraventricular arrhythmias and ventricular premature beats, ventricular tachycardia, or ventricular fibrillation occurred.

\section{Repeated Dose Studies in Rats and Dogs}

After 6 and 12 months' oral administration of prucalopride in rats and dogs, the no-observed-adverse-effect levels were 5 and $10 \mathrm{mg} / \mathrm{kg}$ per day, respectively (data not shown). The corresponding exposure was at least five times higher in rats and 244 times higher in dogs, than that observed in humans who received a daily dose of $2 \mathrm{mg}$.

The highest doses of prucalopride tested were 80 and $30 \mathrm{mg} / \mathrm{kg}$ per day in rats and dogs, respectively. In male rats, increases in heart weight (up to $9 \%$ ) were observed at doses of $20 \mathrm{mg} / \mathrm{kg}$ per day or higher [at least 75 times the human therapeutic area under the curve (AUC)] (data not shown). Cardiac histology revealed an increase in focal infiltration of chronic inflammatory cells in the heart at a dose of $80 \mathrm{mg} / \mathrm{kg}$ per day (at least 785 times the human therapeutic AUC). In dogs, no changes in heart rate, blood pressure, ECG parameters, heart weight, or cardiac histology were observed at any dose tested (the highest dose of $30 \mathrm{mg} / \mathrm{kg}$ per day was 572 times the human therapeutic AUC) (data not shown).

\section{Discussion}

The cardiovascular profile of the highly selective $5-\mathrm{HT}_{4}$ receptor agonist prucalopride was evaluated in an extensive

TABLE 4

Percentage changes from baseline in cardiovascular parameters 5 min after intravenous exposure of anesthetized pigs to prucalopride or solvent (water)

Data are median percentage changes from control values. Changes from baseline of $<10 \%$ vs. control were considered physiologically irrelevant

\begin{tabular}{|c|c|c|c|c|c|c|c|c|c|c|c|c|c|c|c|c|}
\hline \multirow{4}{*}{ Percentage change in parameter } & \multicolumn{16}{|c|}{ Concentration of prucalopride or solvent (mg/kg per minute) } \\
\hline & \multicolumn{8}{|c|}{ Low-dose range ${ }^{a}$} & \multicolumn{8}{|c|}{ High-dose range $^{b}$} \\
\hline & \multicolumn{2}{|c|}{0.02} & \multicolumn{2}{|c|}{0.04} & \multicolumn{2}{|c|}{0.08} & \multicolumn{2}{|c|}{0.16} & \multicolumn{2}{|c|}{0.16} & \multicolumn{2}{|c|}{0.32} & \multicolumn{2}{|c|}{0.63} & \multicolumn{2}{|c|}{1.25} \\
\hline & PRU & SOL & PRU & SOL & PRU & SOL & PRU & SOL & PRU & SOL & PRU & SOL & PRU & SOL & PRU & SOL \\
\hline HR & 9 & -5 & 3 & -8 & 9 & -4 & 22 & -8 & 19 & -2 & 14 & -4 & 7 & -3 & 6 & -6 \\
\hline $\mathrm{AoPd}$ & 7 & -1 & 11 & 5 & 5 & 5 & 0 & 2 & 18 & 0 & 17 & -4 & 17 & -4 & 11 & -8 \\
\hline AoPs & 3 & 0 & 6 & 1 & -3 & 3 & -2 & 0 & 8 & -1 & 7 & -3 & 9 & -3 & 3 & -6 \\
\hline $\mathrm{LVdp} / \mathrm{dt}_{\min }$ & 6 & -4 & 6 & -7 & 1 & -7 & 5 & -11 & 9 & -2 & 11 & -3 & 4 & -3 & 9 & -12 \\
\hline SV & -13 & -5 & -23 & -11 & -26 & -16 & -33 & -14 & -4 & 0 & -16 & -11 & -15 & -12 & -22 & -17 \\
\hline $\mathrm{CO}$ & 6 & -8 & -4 & -17 & 5 & -20 & 9 & -19 & 12 & 2 & -3 & -19 & -9 & -12 & -17 & -17 \\
\hline PRP & 13 & -5 & 4 & -8 & 5 & -1 & 14 & -10 & 29 & -4 & 32 & -2 & 23 & -1 & 12 & -6 \\
\hline Relaxation $(\tau)$ & -1 & 1 & -3 & 11 & -2 & 15 & 7 & 14 & 0 & -2 & 3 & -3 & 8 & -6 & 5 & -3 \\
\hline SVR & 3 & 6 & 13 & 21 & 4 & 25 & -17 & 22 & 5 & 1 & 15 & 6 & 18 & 0 & 17 & -1 \\
\hline PVR & -1 & 5 & 19 & 42 & 29 & 34 & 29 & 28 & -9 & 0 & 10 & 12 & 9 & 24 & 23 & 23 \\
\hline QTcV interval & -4 & -1 & -6 & -5 & -4 & -5 & -6 & -7 & -2 & -1 & -3 & -1 & -4 & -5 & 5 & -5 \\
\hline
\end{tabular}

AoPd, diastolic aortic blood pressure; AoPs, systolic aortic blood pressure; CO, cardiac output; HR, heart rate; PRP, platelet-rich plasma; PRU, prucalopride; PVR,

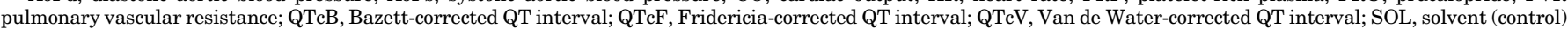
SV, stroke volume; SVR, systemic vascular resistance.

${ }^{a}$ Maximum plasma concentrations ranged from $6.7 \mathrm{ng} / \mathrm{ml}(0.02 \mathrm{mg} / \mathrm{kg})$ to $79.8 \mathrm{ng} / \mathrm{ml}(0.16 \mathrm{mg} / \mathrm{kg})$.

${ }^{b}$ Maximum plasma concentrations ranged from $70 \mathrm{ng} / \mathrm{ml}(0.16 \mathrm{mg} / \mathrm{kg})$ to $757 \mathrm{ng} / \mathrm{ml}(1.25 \mathrm{mg} / \mathrm{kg})$. 
set of studies using a variety of in vitro and in vivo models. Since previously reported adverse cardiovascular events associated with 5- $\mathrm{HT}_{4}$ agonists were attributed to off-target pharmacology, a broad set of studies was implemented to fully exclude all non-5- $\mathrm{HT}_{4}$ receptor-mediated potential cardiovascular interactions. Cardiovascular safety pharmacology studies and toxicology studies were conducted in dogs, where cardiovascular effects such as QT interval prolongation have been shown to have good translation to clinical effects (Jonker et al., 2005). In addition, the effect of prucalopride was evaluated in humans and pigs, because these species bear low levels of cardiac 5- $\mathrm{HT}_{4}$ receptors (De Maeyer et al., 2008). Finally, the effect of chronic cardiovascular exposure to prucalopride was evaluated as part of the toxicology program.

The withdrawn 5- $\mathrm{HT}_{4}$ agonist cisapride was demonstrated to inhibit the hERG potassium channel (essential to the regulation of myocardial repolarization and cardiac rhythmicity) at therapeutic plasma concentrations (Sanguinetti and Tristani-Firouzi, 2006). In contrast, prucalopride, at concentrations comparable with and clearly exceeding those reached after therapeutic dosing in humans $(7.5 \mathrm{ng} / \mathrm{ml})$, had no relevant effect on electrophysiological parameters when studied in various in vitro and in vivo models. Prucalopride had no significant effects on the rapidly activating component of the delayed rectifier potassium current at concentrations up to $1 \mu \mathrm{M}$ (50 times the therapeutic $\mathrm{C}_{\max }$ in man). This clearly dissociates prucalopride from the nonselective $5-\mathrm{HT}_{4}$ receptor agonist cisapride, which has less than 1-fold selectivity for the $5-\mathrm{HT}_{4}$ receptor over the hERG channel (De Maeyer et al., 2008). Prucalopride had no effects on other ion channels at concentrations 500 times higher than the human therapeutic $\mathrm{C}_{\text {max }}$.

In a variety of proarrhythmic cardiovascular models, prucalopride did not exhibit any proarrhythmic tendencies. No biologically relevant effects were identified in rabbit and dog Purkinje fibers, guinea pig papillary muscle, and the isolated rabbit heart, at concentrations 50-500 times the therapeutic $\mathrm{C}_{\max }$ in man. Furthermore, no electrophysiological effects of prucalopride were observed under conditions mimicking bradycardia or hypokalemia. In methoxamine-challenged rabbits, high doses of prucalopride, corresponding to plasma levels over 600 times the human therapeutic $\mathrm{C}_{\max }$, did not elicit ventricular tachycardias, torsades de pointes, or other cardiac arrhythmias.

In the presented studies in anesthetized dogs, prucalopride plasma concentrations reached a median of $1002 \mathrm{ng} / \mathrm{ml}$ (134 times the therapeutic concentration in man), and no significant effects on cardiovascular parameters or ECG time intervals were observed. In anesthetized guinea pigs and rabbits, prucalopride prolonged the duration of the QTc interval only at very high intravenous doses (44 and 350 times the human therapeutic $\mathrm{C}_{\max }$, respectively). Neither the morphology nor the homogeneity of the QT/QTc intervals were changed by prucalopride in rabbits. QT interval dispersion has been proposed as a marker of heterogenous ventricular repolarization and electrical instability in the heart (Day et al., 1990; Carlsson et al., 1993; Lu et al., 1999). Our observation is in agreement with clinical research that showed no change in QT interval dispersion in healthy humans receiving prucalopride (Mendzelevski et al., 2012). An additional phase II trial investigating the safety of prucalopride in elderly patients with constipation similarly reported no differences in ECG or QTc interval between patients who received prucalopride and those who received placebo; no incidences of ventricular arrhythmia were reported after treatment with prucalopride (Camilleri et al., 2009). Our findings are consistent with these clinical studies, and it is therefore unlikely that prucalopride will affect ECG parameters at therapeutic doses.

In conscious dogs, dose-dependent increases in systolic and diastolic blood pressure were observed at prucalopride doses of 0.04 and $0.08 \mathrm{mg} / \mathrm{kg}$. These doses corresponded to plasma levels of two to five times the human therapeutic plasma concentration. Since similar effects were absent in anesthetized dogs, and since $5-\mathrm{HT}_{4}$ receptors are not expressed in canine cardiac tissue, animal restraint, together with the pronounced gastrointestinal motility effect of prucalopride known to occur at these doses, may have contributed to the observed effects.

Putative mechanisms involved in the cardiovascular ischemic events caused by tegaserod include effects on $5-\mathrm{HT}_{1}$ or $5-\mathrm{HT}_{2}$ receptor activity, which may lead to coronary artery constriction or platelet aggregation (De Maeyer et al., 2008; Serebruany et al., 2010). In the platelet aggregation studies presented here, neither prucalopride nor tegaserod caused an increase in aggregation response to a range of physiologically relevant platelet activators. Moreover, alteration in platelet responses to 5 -HT was inhibited by a $5-\mathrm{HT}_{2 \mathrm{~A}}$-selective antagonist, but not a $5-\mathrm{HT}_{4}$-selective antagonist, which indicated that serotonergic platelet aggregation responses are mediated through $5-\mathrm{HT}_{2 \mathrm{~A}}$ receptors. Tegaserod has been shown to be a $5-\mathrm{HT}_{2}$ receptor antagonist (Beattie et al., 2004), whereas prucalopride has no affinity for these receptors (De Maeyer et al., 2008) and induced no contractile effects at concentrations up to 500 times higher than human therapeutic $\mathrm{C}_{\max }$. Tegaserod induced contraction in canine tissue only; this may be related to its affinity for $5-\mathrm{HT}_{1 \mathrm{~B}}$ receptors (De Maeyer et al., 2008).

Prucalopride ( $1 \mathrm{nM}-10 \mu \mathrm{M})$ caused a concentration-dependent increase in sinoatrial beating rate in piglet atrial myocardium, and in contractile force in human right atria. These observations are consistent with previously described modest effects of prucalopride in porcine atrial myocardium (De Maeyer et al., 2006a). The selective $5-\mathrm{HT}_{4}$ receptor antagonist GR113808 completely attenuated the chronotropic and inotropic effects of prucalopride, indicating that these effects were $5-\mathrm{HT}_{4}$-mediated. Human and porcine hearts have a very low density of $5-\mathrm{HT}_{4}$ receptors, with no receptor reserve for 5-HT in atrial tissue (De Maeyer et al., 2006b, 2009). Consequently, prucalopride behaved as a weak partial agonist compared with 5-HT (i.e., was less efficacious than 5-HT); as a result, prucalopride can antagonize the effects of exogenous 5-HT and may possibly provide a protective effect against endogenously released 5-HT.

In anesthetized pigs, a slight and transient increase in heart rate and systolic and diastolic blood pressure was noted at plasma levels at least 10 times higher than the human therapeutic $\mathrm{C}_{\text {max }}$. This transient increase in heart rate decreased gradually over a 30-minute period, and higher doses administered subsequently did not have the same effect. These observations, together with the presented findings from studies in porcine and human atrial myocardium, may explain the transient and limited increases in heart rate (2-5 beats/min) observed in healthy volunteers upon first exposure to prucalopride (2 and $10 \mathrm{mg}$ ) (Mendzelevski et al., 2012). In a thorough QT study 
and in two phase I cardiovascular trials, healthy volunteers who received prucalopride at up to 10 times the therapeutic dose demonstrated slight and transient increases in heart rate by $5-8$ beats/min. These effects faded after an initial peak at 3 hours after dosing (Boyce et al., 2009; Mendzelevski et al., 2012). Furthermore, compared with the long-lasting $5-\mathrm{HT}_{4}$ receptormediated stimulatory effects of prucalopride observed in the stomach and colon of guinea pigs, rats, and dogs (Tack et al., 2012; Tack and Corsetti, 2012), the chronotropic and inotropic effects of prucalopride in the human and porcine heart have been shown to diminish rapidly (De Maeyer et al., 2009).

In repeated dose toxicity studies, no effects of prucalopride on ECG characteristics, heart rate, or blood pressure were observed in conscious dogs [up to $30 \mathrm{mg} / \mathrm{kg}$ per day for 12 months (572 times the human therapeutic AUC)].

In conclusion, non-5- $\mathrm{HT}_{4}$ receptor-mediated pharmacology has been implicated in the etiology of cardiovascular adverse events for the withdrawn first-generation $5-\mathrm{HT}_{4}$ receptor agonists cisapride and tegaserod. No relevant effects on cardiovascular and cardiac electrophysiological parameters were observed at prucalopride concentrations of at least 50 times the human therapeutic $\mathrm{C}_{\max }$. Only small, transient increases in heart rate and blood pressure were observed in anesthetized pigs at prucalopride concentrations 10 times higher than the human therapeutic $\mathrm{C}_{\max }$. Prucalopride demonstrated a wide safety margin, with physiologically significant effects on electrophysiological and cardiovascular parameters observed only at supratherapeutic concentrations that were considered clinically irrelevant. Preclinical and clinical evidence together support the improved cardiovascular safety offered by prucalopride compared with other nonselective $5-\mathrm{HT}_{4}$ receptor agonists in the treatment of patients with gastrointestinal motility disorders such as chronic idiopathic constipation.

\section{Acknowledgments}

Atrial myocardium studies were performed by Dr. Alberto Kaumann, University of Cambridge, Cambridge, UK. The authors thank Dr. Galen Carey (Shire, Lexington, MA) for his review and comments. Medical writing support was provided by Laura Knapp, PharmaGenesis London, London, UK, with funding from Shire.

\section{Authorship Contributions}

Participated in research design: De Maeyer, Schuurkes, Christie, McRedmond, Conlon, Wade.

Conducted experiments: Christie, De Maeyer, McRedmond, Schuurkes.

Performed data analysis: De Maeyer, Schuurkes, Christie, McRedmond, Derakhchan, Wade.

Wrote or contributed to the writing of the manuscript: Conlon, Bruce, De Maeyer, Schuurkes, Christie, McRedmond, Derakhchan, Wade.

\section{References}

Adamantidis MM, Dumotier BM, Caron JF, and Bordet R (1998) Sparfloxacin but not levofloxacin or ofloxacin prolongs cardiac repolarization in rabbit Purkinje fibers. Fundam Clin Pharmacol 12:70-76.

Anderson JL, May HT, Bair TL, Muhlestein JB, Horne iBD, and Carlquist JF (2009) Lack of association of tegaserod with adverse cardiovascular outcomes in a matched case-control study. J Cardiovasc Pharmacol Ther 14:170-175.

Beattie DT, Smith JAM, Marquess D, Vickery RG, Armstrong SR, Pulido-Rios T, McCullough JL, Sandlund C, Richardson C, Mai N, et al. (2004) The 5-HT receptor $^{-}$ agonist, tegaserod, is a potent $5-\mathrm{HT}_{2 \mathrm{~B}}$ receptor antagonist in vitro and in vivo. $\mathrm{Br} J$ Pharmacol 143:549-560.

Bliss CI (1939) The toxicity of poisons applied jointly. Ann Appl Biol 26:585-615.

Bosshard W, Dreher R, Schnegg JF, and Büla CJ (2004) The treatment of chronic constipation in elderly people: an update. Drugs Aging 21:911-930.
Boyce MJ, Kerstens R, Beyens G, Ausma J, and Vandeplassche L (2009) T1265 cardiovascular safety of prucalopride in healthy subjects: results from two randomized, doubleblind, placebo-controlled, cross-over trials. Gastreoenterology 136:A535.

Briejer MR, Bosmans JP, Van Daele P, Jurzak M, Heylen L, Leysen JE, Prins NH, and Schuurkes JA (2001) The in vitro pharmacological profile of prucalopride, a novel enterokinetic compound. Eur J Pharmacol 423:71-83.

Camilleri M, Beyens G, Kerstens R, Robinson P, and Vandeplassche L (2009) Safety assessment of prucalopride in elderly patients with constipation: a double-blind, placebo-controlled study. Neurogastroenterol Motil 21:1256-e117.

Camilleri M, Kerstens R, Rykx A, and Vandeplassche L (2008) A placebo-controlled trial of prucalopride for severe chronic constipation. $N$ Engl J Med 358:2344-2354.

Carlsson L, Abrahamsson C, Andersson B, Duker G, and Schiller-Linhardt G (1993) Proarrhythmic effects of the class III agent almokalant: importance of infusion rate, QT dispersion, and early after depolarisations. Cardiovasc Res 27:2186-2193.

Carlsson L, Amos GJ, Andersson B, Drews L, Duker G, and Wadstedt G (1997) Electrophysiological characterization of the prokinetic agents cisapride and mosapride in vivo and in vitro: implications for proarrhythmic potential? J Pharmacol Exp Ther 282:220-227.

Carmeliet E, Xhonneux R, Van Glabbeek A, and Reneman R (1976) Electrophysiological effects of droperidol in different cardiac tissues. Naunyn Schmiedebergs Arch Pharmacol 293:57-66

Day CP, McComb JM, and Campbell RW (1990) QT dispersion: an indication of arrhythmia risk in patients with long QT intervals. Br Heart $J$ 63:342-344.

De Maeyer JH, Lefebvre RA, and Schuurkes JA (2008) 5-HT4 receptor agonists: similar but not the same. Neurogastroenterol Motil 20:99-112.

De Maeyer JH, Prins NH, Schuurkes JA, and Lefebvre RA (2006b) Differential effects of 5-hydroxytryptamine4 receptor agonists at gastric versus cardiac receptors: an operational framework to explain and quantify organ-specific behavior. $J$ Pharmacol Exp Ther 317:955-964.

De Maeyer JH, Schuurkes JA, and Lefebvre RA (2009) Selective desensitization of the $5-\mathrm{HT}_{4}$ receptor-mediated response in pig atrium but not in stomach. $\mathrm{Br} J$ Pharmacol 156:362-376.

De Maeyer JH, Straetemans R, Schuurkes JA, and Lefebvre RA (2006a) Porcine left atrial and sinoatrial 5-HT( $\left.{ }_{4}\right)$ receptor-induced responses: fading of the response and influence of development. Br J Pharmacol 147:140-157.

Dennison C, Prasad M, Lloyd A, Bhattacharyya SK, Dhawan R, and Coyne K (2005) The health-related quality of life and economic burden of constipation. Pharmacoeconomics 23:461-476.

Gershon MD and Tack J (2007) The serotonin signaling system: from basic understanding to drug development for functional GI disorders. Gastroenterology 132:397-414.

Higgins PD and Johanson JF (2004) Epidemiology of constipation in North America: a systematic review. Am J Gastroenterol 99:750-759.

Hondeghem LM, Carlsson L, and Duker G (2001) Instability and triangulation of the action potential predict serious proarrhythmia, but action potential duration prolongation is antiarrhythmic. Circulation 103:2004-2013.

Jin J and Kunapuli SP (1998) Coactivation of two different G protein-coupled receptors is essential for ADP-induced platelet aggregation. Proc Natl Acad Sci USA 95:8070-8074.

Jonker DM, Kenna LA, Leishman D, Wallis R, Milligan PA, and Jonsson EN (2005) A pharmacokinetic-pharmacodynamic model for the quantitative prediction of dofetilide clinical QT prolongation from human ether-a-go-go-related gene current inhibition data. Clin Pharmacol Ther 77:572-582.

Kaumann AJ, Sanders L, Brown AM, Murray KJ, and Brown MJ (1990) A 5-hydroxytryptamine receptor in human atrium. $\mathrm{Br} J$ Pharmacol 100:879-885.

Loewe S (1953) The problem of synergism and antagonism of combined drugs. Arzneimittelforschung 3:285-290.

Loughlin J, Quinn S, Rivero E, Wong J, Huang J, Kralstein J, Earnest DL, and Seeger JD (2010) Tegaserod and the risk of cardiovascular ischemic events: an observational cohort study. J Cardiovasc Pharmacol Ther 15:151-157.

Lu HR, Yu F, Dai DZ, Remeysen P, and De Clerck F (1999) Reduction in QT dispersion and ventricular arrhythmias by ischaemic preconditioning in anaesthetized, normotensive and spontaneously hypertensive rats. Fundam Clin Pharmacol 13:445-454.

Mendzelevski B, Ausma J, Chanter DO, Robinson P, Kerstens R, Vandeplassche L, and Camm J (2012) Assessment of the cardiac safety of prucalopride in healthy volunteers: a randomized, double-blind, placebo- and positive-controlled thorough QT study. Br J Clin Pharmacol 73:203-209.

Mohammad S, Zhou Z, Gong Q, and January CT (1997) Blockage of the HERG human cardiac $\mathrm{K}^{+}$channel by the gastrointestinal prokinetic agent cisapride. Am J Physiol 273:H2534-H2538.

Potet F, Bouyssou T, Escande D, and Baró I (2001) Gastrointestinal prokinetic drugs have different affinity for the human cardiac human ether-à-gogo $\mathrm{K}(+)$ channel. $J$ Pharmacol Exp Ther 299:1007-1012.

Quigley EM, Vandeplassche L, Kerstens R, and Ausma J (2009) Clinical trial: the efficacy, impact on quality of life, and safety and tolerability of prucalopride in severe chronic constipation-a 12-week, randomized, double-blind, placebocontrolled study. Aliment Pharmacol Ther 29:315-328.

Rampe D, Roy ML, Dennis A, and Brown AM (1997) A mechanism for the proarrhythmic effects of cisapride (Propulsid): high affinity blockade of the human cardiac potassium channel HERG. FEBS Lett 417:28-32.

Redfern WS, Carlsson L, Davis AS, Lynch WG, MacKenzie I, Palethorpe S, Siegl PK Strang I, Sullivan AT, Wallis R, et al. (2003) Relationships between preclinical cardiac electrophysiology, clinical QT interval prolongation and torsade de pointes for a broad range of drugs: evidence for a provisional safety margin in drug development. Cardiovasc Res 58:32-45.

Sanguinetti MC and Tristani-Firouzi M (2006) hERG potassium channels and cardiac arrhythmia. Nature 440:463-469.

Serebruany VL, El Mouelhi M, Pfannkuche HJ, Rose K, Marro M, and Angiolillo DJ (2010) Investigations on 5- $\mathrm{HT}_{4}$ receptor expression and effects of tegaserod on human platelet aggregation in vitro. Am $J$ Ther 17:543-552. 
Smith JA, Beattie DT, Marquess D, Shaw JP, Vickery RG, and Humphrey PP (2008) The in vitro pharmacological profile of TD-5108, a selective 5-HT( ${ }_{4}$ ) receptor agonist with high intrinsic activity. Naunyn Schmiedebergs Arch Pharmacol 378:125-137.

Tack J, Camilleri M, Chang L, Chey WD, Galligan JJ, Lacy BE, Müller-Lissner S, Quigley EM, Schuurkes J, De Maeyer JH, et al. (2012) Systematic review: cardiovascular safety profile of 5 - $\mathrm{HT}_{4}$ ) agonists developed for gastrointestinal disorders. Aliment Pharmacol Ther 35:745-767.

Tack J and Corsetti M (2012) Prucalopride: evaluation of the pharmacokinetics, pharmacodynamics, efficacy and safety in the treatment of chronic constipation. Expert Opin Drug Metab Toxicol 8:1327-1335.

Tack J, van Outryve M, Beyens G, Kerstens R, and Vandeplassche L (2009) Prucalopride (resolor) in the treatment of severe chronic constipation in patients dissatisfied with laxatives. Gut 58:357-365.

Wald A, Scarpignato C, Kamm MA, Mueller-Lissner S, Helfrich I, Schuijt C, Bubeck J, Limoni C, and Petrini O (2007) The burden of constipation on quality of life: results of a multinational survey. Aliment Pharmacol Ther $\mathbf{2 6}$ : $227-236$.

Yiannakou Y, Piessevaux H, Bouchoucha M, Schiefke I, Filip R, Gabalec L, Dina I, Stephenson D, Kerstens R, Etherson K, et al. (2015) A randomized, double-blind, placebo-controlled, phase 3 trial to evaluate the efficacy, safety, and tolerability of prucalopride in men with chronic constipation. Am $J$ Gastroenterol 110: $741-748$.

Zhou Z, Gong Q, Ye B, Fan Z, Makielski JC, Robertson GA, and January CT (1998) Properties of HERG channels stably expressed in HEK 293 cells studied at physiological temperature. Biophys J 74:230-241.

Address correspondence to: Dr. Paul R. Wade, 1628 North Street, Philadelphia, PA 19130-3305. E-mail: paulrwade@comcast.net 